Article

\title{
Contribution of Remote Sensing Technologies to a Holistic Coastal and Marine Environmental Management Framework: A Review
}

\author{
Badr El Mahrad ${ }^{1,2,3, *}$, , Alice Newton ${ }^{3}$, John D. Icely ${ }^{3,4}{ }^{\circ}$, Ilias Kacimi ${ }^{2}$, Samuel Abalansa ${ }^{3}$ \\ and Maria Snoussi ${ }^{5}$ \\ 1 Murray Foundation, Brabners LLP, Horton House, Exchange Street, Liverpool L2 3YL, UK \\ 2 Laboratory of Geoscience, Water and Environment, (LG2E-CERNE2D), Department of Earth Sciences, \\ Faculty of Sciences, Mohammed V University of Rabat, Rabat 10000, Morocco; iliaskacimi@yahoo.fr. \\ 3 CIMA, FCT-Gambelas Campus, University of Algarve, 8005-139 Faro, Portugal; anewton@ualg.pt (A.N.); \\ john.icely@gmail.com (J.D.I.); abalansas@gmail.com (S.A.) \\ 4 Sagremarisco, Apartado 21, 8650-999 Vila do Bispo, Portugal \\ 5 Department of Earth Sciences, Faculty of Sciences, Mohammed V University of Rabat, Rabat 10000, Morocco; \\ snoussi@fsr.ac.ma \\ * Correspondence: badr.elmahrad@gmail.com
}

Received: 1 May 2020; Accepted: 13 July 2020; Published: 18 July 2020

check for updates

\begin{abstract}
Coastal and marine management require the evaluation of multiple environmental threats and issues. However, there are gaps in the necessary data and poor access or dissemination of existing data in many countries around the world. This research identifies how remote sensing can contribute to filling these gaps so that environmental agencies, such as the United Nations Environmental Programme, European Environmental Agency, and International Union for Conservation of Nature, can better implement environmental directives in a cost-effective manner. Remote sensing (RS) techniques generally allow for uniform data collection, with common acquisition and reporting methods, across large areas. Furthermore, these datasets are sometimes open-source, mainly when governments finance satellite missions. Some of these data can be used in holistic, coastal and marine environmental management frameworks, such as the DAPSI(W)R(M) framework (Drivers-Activities-Pressures-State changes-Impacts (on Welfare)-Responses (as Measures), an updated version of Drivers-Pressures-State-Impact-Responses. The framework is a useful and holistic problem-structuring framework that can be used to assess the causes, consequences, and responses to change in the marine environment. Six broad classifications of remote data collection technologies are reviewed for their potential contribution to integrated marine management, including Satellite-based Remote Sensing, Aerial Remote Sensing, Unmanned Aerial Vehicles, Unmanned Surface Vehicles, Unmanned Underwater Vehicles, and Static Sensors. A significant outcome of this study is practical inputs into each component of the DAPSI(W)R(M) framework. The RS applications are not expected to be all-inclusive; rather, they provide insight into the current use of the framework as a foundation for developing further holistic resource technologies for management strategies in the future. A significant outcome of this research will deliver practical insights for integrated coastal and marine management and demonstrate the usefulness of RS to support the implementation of environmental goals, descriptors, targets, and policies, such as the Water Framework Directive, Marine Strategy Framework Directive, Ocean Health Index, and United Nations Sustainable Development Goals. Additionally, the opportunities and challenges of these technologies are discussed.
\end{abstract}

Keywords: remote sensing; DPSIR; coastal and marine management; environmental policies and directives; WFD; MSFD; ocean health index; sustainable development goals 


\section{Introduction}

Coastal zones are among the most populated areas on the planet $[1,2]$. As the population continues to increase, economic development must expand to support human welfare. However, this development may damage the coastal environment that is supporting human welfare for current and future generations [3]. The management of complex coastal and marine social-ecological systems (SES) requires tools that provide frameworks with the capability of responding to current and emergent issues in these SES [4].

Many frameworks have been developed that address and integrate complex issues to provide solutions. For example, the Millennium Ecosystem Assessment framework [5], which links drivers, ecosystem services, and human welfare; the Ostrom framework [6], which analyses the sustainability of social-ecological systems; and the Drivers-Activities-Pressures-State change-Impact (on Welfare)-Responses (as Measures) framework, "DAPS(W)R(M)", which relates ecosystem services to societal and economic pressures [7].

However, obtaining the environmental data that is necessary to use these frameworks is difficult, especially in countries where access to reliable data and their dissemination are limited or non-existent [8] and even thwarted. Ndzabandzaba, 2015 [9] raised awareness of the Global Sustainable Development Report regarding data sharing and their essential role in decision-making and as a key for further progress [9]. For instance, the European Union Directives (e.g., Water Framework Directive (WFD) [10] and Marine Strategy Framework Directive (MSFD) [11]) require continuous environmental monitoring and sharing data in a consistent and transparent manner [12], despite the complexity and cost of this obligation. Furthermore, countries worldwide that are signatories to Regional Sea conventions (e.g., OSPAR, HELCOM, and Barcelona Convention) must also monitor accordingly. For this purpose, these countries are mainly using the targets of the Sustainable Development Goals (SDGs) $[13,14]$ and the goals of the Ocean Health Index (OHI) [15].

Traditional techniques of point sampling and observation in the environment do deliver high information content [16], but they are expensive and often do not provide adequate spatial and temporal coverage, while remote sensing can provide cost-effective solutions, as well as data for locations where there is no or only limited information [17].

The new Millennium era of data collection through earth observation technologies and sensors is becoming more widely used for monitoring sectors related to the coastal and marine environment [16,18-27]. As these data are collected routinely, they could provide a basis for synoptic-scale analysis covering a larger area over a time series. Furthermore, these datasets are sometimes open-source and easily accessible, especially when data acquisition is realized by government bodies and institutions, providing a large volume of freely accessible data for analysis and dissemination.

This research highlights and reviews the potential use of six remote data collecting technologies for improving integrated coastal and marine environmental management based on DAPSI(W)R(M) [7], an updated version of the widely used Driver-Pressure-State-Impact-Response framework (DPSIR) [28]. The research follows a sequence from large- to small-scale technologies, including Satellite Remote Sensing (SRS), Aerial Remote Sensing (ARS), Unmanned Aerial Vehicles (UAV), Unmanned Surface Vehicles (USV), Unmanned Underwater Vehicles (UUV), and Static Sensors as Ground Methods (SS). The opportunities and challenges of these technologies are described briefly. Their applications are not meant to be exhaustive, but rather to provide knowledge on their use for holistic management, such as supplying missing data, as well as providing a foundation for future research using RS technologies. Examples are provided how these RS technologies can be useful for all components of the DAPSI $(\mathrm{W}) \mathrm{R}(\mathrm{M})$ framework. 


\section{Materials and Methods}

\subsection{The DAPSI $(W) R(M)$ Framework}

The DPSIR framework is one of the primary tools used for adaptive management of socio-ecological systems; it was initially developed by the Organization of Economic Cooperation and Development [29] and then adopted by the European Environment Agency [30] and continues to be used extensively throughout the world [28]. However, there has been confusion between components of the framework, which have been resolved by further development of in the form of DAPSI(W)R(M) [7], whereby Drivers represent the basic human needs that require Activities, which lead to Pressures that are the mechanisms of State change on the natural system; the subsequent Impacts (on human Welfare) require Responses (as Measures).

\subsection{Remote Sensing Applications that Could be Used for DAPSI(W)R(M) Analysis}

While DAPSI $(\mathrm{W}) \mathrm{R}(\mathrm{M})$ is increasingly used as a holistic framework for integrated coastal and marine management [4,31-36], there has only been limited use of RS technologies to support this management framework. For instance, [37] addressed satellite and airborne remote sensing for supporting Marine Spatial Planning (MSP) and Integrated Coastal Area Management (ICAM) by providing a list of relevant sensors. Strong and Elliot., 2017 [16] provided guidance on remote sensing techniques that can facilitate the extrapolation process by structuring RS data effectively across multiple spatial scales in order to undertake a correct assessment for integrated marine management. Fingas, 2019 [20] presented an overview of the use of optical satellites and sensors used for ocean management and that provide a mapping of several parameters.

Remote sensing technologies have played a significant role in sensing the environment during the last five decades [38]. There seem to be two different types of approaches in the literature, namely general overviews of RS technologies focusing on a single issue or a general overview of one RS technology to solve various issues. Side and Jowitt., 2002 [39] compared remote sensing technologies for seabed mapping by providing coverage and resolution. Goetz, 2009 [40] presented an overview of decades of existing hyperspectral RS for analysing the earth. Kratzer et al., 2014 [41] developed a conceptual model to integrate ocean colour remote sensing data into coastal management with a case study in Himmerfjärden in Sweden. Unninayar and Olsen., 2015 [25] presented a global dimension on the use of satellites to monitor and observe the earth. Vihervaara et al., 2017 [23] showed the role of remote sensing combined with essential biodiversity variables on improving the current state of biodiversity in Finland. Guo et al., 2017 [26] reviewed seven types of sensors applied to wetlands, including their classification, water quality, sea-level rise, and other parameters, by presenting their advantages and limitations and providing advice on future wetland-RS research lines. Bean et al., 2017 [27] discussed the impact of RS technologies onmonitoring the whole marine ecosystem models for an integrated and comprehensive approach to impact assessments that can benefit the society in the context of a country, such as the UK. Neukermans et al., 2018 [42] addressed critical science questions on ocean-atmosphere interaction using multiplatform space-borne missions, from visible to microwave, active, and passive sensors. Werdell et al., 2018 [43] have presented state of the art approaches to obtain marine inherent optical properties from ocean colour RS and have defined the areas where existing knowledge gaps remain. Murray et al., 2018 [24] suggested a framework for integrating RS data into ecosystem risk assessments and showed that unstructured use of RS data could introduce substantial error and uncertainty into this assessment.

In the present article, six categories of RS technologies are considered (Figure 1): 


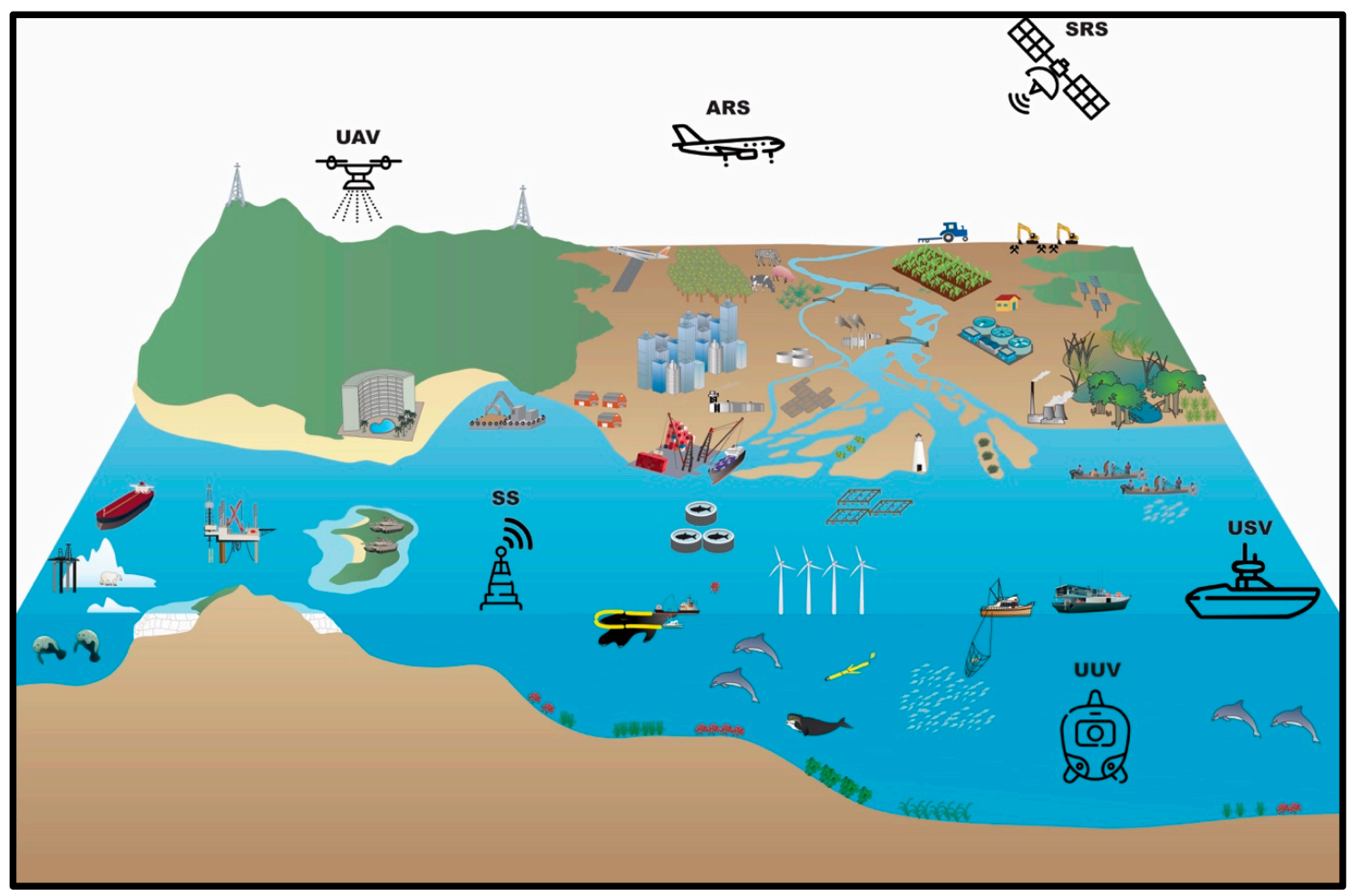

Figure 1. Conceptual diagram summarizing the main activities in coastal and marine environment and the relevant remote sensing technologies for their assessment. Symbols are courtesy of the Integartion and Application Network, University of Maryland Center for Environmental Science (https://ian.umces.edu/symbols/). (Credit: Badr El Mahrad).

Satellite Remote Sensing (SRS): Land surface observations using satellite images started in the early seventies with the launching of Landsat 1. During the late seventies, the Coastal Zone Colour Scanner was launched as the first satellite intended for monitoring the Earth's oceans and water bodies by observing ocean colour and temperature, particularly in coastal zones [44]. Later, many other satellite sensors were developed by several space agencies and countries. Krug et al., 2016 [44] provided a list (https://ars.els-cdn.com/content/image/1-s2.0-S0079661116301562-mmc1.pdf) of orbital sensors dedicated to ocean colour radiometry from 1970 to satellites proposed for the future. In general, satellite-based remote sensing images and techniques are advantageous as they usually collect uniform data with common acquisition and recording schemes, covering large areas. Furthermore, other types of sampling missions can be expensive and infrequent, which can hinder analyses that requires data with high temporal fidelity [18]. A full review of SRS sensors can be found in [45] and [46].

Aerial Remote Sensing or Manned Aircraft (ARS): This technique is known as aerial photography or airborne imagery and is based on taking photographs from a human-crewed aircraft. The first aerial photograph from a hot air balloon dates back to 1858 [47]. It started in manned aircraft in 1909 and advanced, especially during world wars. For example, since the 1930s, the United States has covered most locations in the country, using photogrammetric techniques [48]. Manned aircraft can offer further objective and replicable outcomes with a permanent record [49]. They have succeeded in many aspects of coastal research, such as wetland assessments, beach erosion control, land-use planning, coral reefs, marine habitat, and many others [50-52].

Unmanned aerial vehicles (UAVs): Most known vehicles in this category are drones, which are unmanned aircraft that can reach difficult locations, such as wetlands. Traditionally these are used in military surveillance missions. Their use has been growing rapidly since the beginning of the 21st century with an unprecedented development for missions with high social impact [53] and for different types of environments, such as coastal areas $[54,55]$ and marine areas [56,57]. Papakonstantinou et al., 
2016 [58] suggested a 3D representation that can improve the classification, visualization, and mapping of coastal morphology in high resolution, using UAV images. Furthermore, [59] provided a protocol for UAV aerial survey that can improve data acquisition quality, in a timely, efficient manner that represents an effective methodology for coastal and marine survey. A full review of UAVs for photogrammetry and remote sensing is provided by [60].

Unmanned Surface Vehicles (USVs): These are vehicles that operate on the water surface without a crew. They are also called autonomous surface vehicles, unmanned surface vessels, or autonomous surface crafts. Significant progress in the development of USVs occurred from the end of the 20 th century into the 21st century [61,62]. USVs have been used for many aspects related to marine management, such as bathymetry surveys [63], sea surface sampling [64], environmental data gathering, pollutant tracking [65,66], harmful algal bloom detection [67], meteorological parameters [68], and even monitoring of marine fauna $[69,70]$. An overview of USV developments and challenges is presented by [71].

Unmanned Underwater Vehicles (UUVs): These are robotic devices or vehicles that are unmanned underwater. Their deployment allows the study of many aspects of the marine environment, such as in marine geoscience [72], monitoring marine habitat [73,74], mapping the seafloor [75], marine archaeology [76], underwater structures [77], and many other aspects. Sahoo et al., 2019 [78] presented the advances in the field of UUVs.

Static Sensors (SS) as Ground Methods: These include single sensors or wireless sensor networks (WSN). They are growing in the field of environmental resource management [18] and have many users for coastal and marine environments. These sensors can measure upwellings [79], oil spills [79], water quality, fish behaviour [80], and storm detection [81]. They can also be used as biosensors for monitoring marine contaminants [82] and many other applications [83]. However, as they are typically fixed sensors, each individual sensor delivers only local observations.

Comparing these different remote sensing technologies, SRS have larger spatial coverage with large-volume time series, non-destructive sampling capabilities, and are cost-effective [84,85]. The launch of SENTINEL missions by the European Space Agency (ESA) under the COPERNICUS program demonstrated the importance of these technologies. They are the most ambitious earth observation (EO) systems worldwide [86] with more than 15,000 users registered in 2019 to the Copernicus Marine Environment Monitoring Service (CMEMS) alone, which will probably increase further after the launch of all Sentinel constellations [21].

\section{Results}

The results below show the RS applications for the interconnections between DAPSI(W)R(M) and RS technologies, focusing on each component of the framework. This information will help to fill the knowledge gap required to achieve holistic, integrated coastal and marine management.

The findings that are presented in Tables 1-3 are of potential value for decision-makers, researchers, managers, engineers, and other stakeholders working on technical aspects. For example, a coastal manager working on eutrophication may be interested in assessing how much intensive agriculture there is in a catchment. The manager can choose to use "area of greenhouses" as an indicator of intensive agriculture. Using Table 1, the manager can find the research developed by [87]. However, the manager can also find the research of [88] in Table 2 (pressures section), which can provide information about the type of crop, as well as provide some information about the quantity of fertilizer and nutrient ratios shown by the research of [89]. Furthermore, the manager can also assess the distribution of harmful algal blooms as a state change in Table 3, and follow the techniques used by [90]. 
Table 1. A review of the remote sensing applications that are being developed for activities related to the economic sectors in coastal and marine areas.

\begin{tabular}{|c|c|c|c|c|c|c|}
\hline Sector & Type of Activity & $\begin{array}{l}\text { RS technology } \\
\text { SRS, ARS, UAV, } \\
\text { USV, UUV, SS }\end{array}$ & $\begin{array}{c}\text { If SRS Data } \\
\text { Satellite }\end{array}$ & Description/Application & Reference & $\begin{array}{c}\text { Environment } \\
\text { Coastal/Marine }\end{array}$ \\
\hline General & & & & Remote sensing for marine management & [20] & $\mathrm{C} / \mathrm{M}$ \\
\hline \multirow{6}{*}{ Agriculture } & \multirow{3}{*}{ General } & SRS & - & Monitoring of agricultural landscapes & [91] & $\mathrm{C}$ \\
\hline & & SRS & - & $\begin{array}{c}\text { SAR for agriculture applications: } \\
\text { Review }\end{array}$ & [92] & $\mathrm{C}$ \\
\hline & & SRS & - & $\begin{array}{l}\text { A comparison of eight global and } \\
\text { regional agricultural monitoring systems }\end{array}$ & [93] & $\mathrm{C}$ \\
\hline & Coastal Forestry & SRS & Landsat & $\begin{array}{c}\text { Visualizing coastal forest dynamics by } \\
\text { SRS }\end{array}$ & [94] & $\mathrm{C}$ \\
\hline & \multirow{2}{*}{$\begin{array}{l}\text { Coastal Farming } \\
\text { (Greenhouses) }\end{array}$} & SRS & Landsat \& Worldview 2 & $\begin{array}{l}\text { Detection of horticultural crops under } \\
\text { greenhouses using multi-temporal SRS }\end{array}$ & [88] & C \\
\hline & & SRS & Landsat ETM+ & $\begin{array}{c}\text { Developing a new spectral index for } \\
\text { mapping greenhouse using medium } \\
\text { spatial resolution SRS }\end{array}$ & [87] & $\mathrm{C}$ \\
\hline \multirow{2}{*}{$\begin{array}{l}\text { Livestock } \\
\text { Golf }\end{array}$} & & UAV & - & Detecting livestock in UAV images & [95] & $\mathrm{C}$ \\
\hline & & SRS & SPOT 5 & $\begin{array}{c}\text { Golf course detection using } \\
\text { multispectral remote sensing imagery }\end{array}$ & [96] & $\mathrm{C}$ \\
\hline \multirow[t]{3}{*}{ Damming } & & SRS & Sentinel 1 & $\begin{array}{l}\text { Deformation effects of dams on coastal } \\
\text { regions using sentinel-1 images }\end{array}$ & [97] & $\mathrm{C}$ \\
\hline & \multirow{2}{*}{ General } & SRS & - & $\begin{array}{c}\text { Aquaculture: Relevance, distribution, } \\
\text { impacts and spatial assessments-A } \\
\text { review }\end{array}$ & [98] & $\mathrm{C} / \mathrm{M}$ \\
\hline & & UUV & - & $\begin{array}{l}\text { Integrated navigation for autonomous } \\
\text { underwater vehicles in aquaculture: A } \\
\text { review }\end{array}$ & [99] & M \\
\hline \multirow[t]{3}{*}{ Aquaculture } & Tank & SS & - & $\begin{array}{l}\text { Static sensors for monitoring the water } \\
\text { quality and fish behavior in aquaculture } \\
\text { tanks }\end{array}$ & [80] & $\mathrm{C} / \mathrm{M}$ \\
\hline & Ponds & SRS & Landsat/Sentinel 1 & $\begin{array}{l}\text { Remote monitoring of expansion of } \\
\text { aquaculture ponds along a coastal region }\end{array}$ & [100] & $\mathrm{C}$ \\
\hline & Shellfishery & $\begin{array}{l}\text { SRS } \\
\text { ARS }\end{array}$ & $\begin{array}{c}\text { TerraSAR-X/SPOT } 5 \& \\
\text { Hyspex } \\
\end{array}$ & $\begin{array}{c}\text { Hyperspectral remote sensing of wild } \\
\text { oyster reefs }\end{array}$ & [101] & $\mathrm{C} / \mathrm{M}$ \\
\hline \multirow[b]{2}{*}{$\begin{array}{l}\text { Extraction of Living } \\
\text { Resources }\end{array}$} & Fishing & SRS/ARS/USV & - & $\begin{array}{l}\text { Fisheries applications of remote sensing: } \\
\text { An overview }\end{array}$ & [102] & $\mathrm{M}$ \\
\hline & $\begin{array}{c}\text { Seaweed and } \\
\text { saltmarsh harvesting }\end{array}$ & SRS & - & $\begin{array}{l}\text { The remote sensing of biodiversity: from } \\
\text { global to local scales }\end{array}$ & [103] & $\mathrm{C} / \mathrm{M}$ \\
\hline
\end{tabular}


Table 1. Cont.

\begin{tabular}{|c|c|c|c|c|c|c|}
\hline Sector & Type of Activity & $\begin{array}{l}\text { RS technology } \\
\text { SRS, ARS, UAV, } \\
\text { USV, UUV, SS }\end{array}$ & $\begin{array}{c}\text { If SRS Data } \\
\text { Satellite }\end{array}$ & Description/Application & Reference & $\begin{array}{c}\text { Environment } \\
\text { Coastal/Marine }\end{array}$ \\
\hline \multirow[b]{2}{*}{$\begin{array}{l}\text { Extraction of Non-Living } \\
\text { Resources }\end{array}$} & Coastal sand mining & SRS & ALOS & $\begin{array}{l}\text { Characterization of black sand mining } \\
\text { activities using remote sensing }\end{array}$ & [104] & C \\
\hline & $\begin{array}{l}\text { Onshore mineral } \\
\text { extraction }\end{array}$ & SRS & - & $\begin{array}{l}\text { Assessing impacts of mining: Recent } \\
\text { contributions from GIS and remote } \\
\text { sensing }\end{array}$ & [105] & C \\
\hline \multirow{6}{*}{ Tourism and Recreation } & General & $\begin{array}{l}\text { SRS /ARS } \\
\text { UAV }\end{array}$ & - & $\begin{array}{c}\text { Interaction between a protected } \\
\text { destination system and conservation } \\
\text { tourism through RS }\end{array}$ & [106] & $\mathrm{C} / \mathrm{M}$ \\
\hline & \multirow[t]{2}{*}{ Swimming pool } & SRS & Worldview 2 & $\begin{array}{l}\text { Integrating machine learning techniques } \\
\text { and high-resolution RSR imagery to } \\
\text { generate GIS-ready information for } \\
\text { urban water consumption }\end{array}$ & [107] & $C$ \\
\hline & & ARS & - & $\begin{array}{l}\text { ARS data to support the estimation of } \\
\text { water use in private swimming pools }\end{array}$ & [108] & C \\
\hline & \multirow[t]{2}{*}{ Beach use } & SRS & $\begin{array}{l}\text { Landsat } 8 \\
\text { Sentinel-2 }\end{array}$ & Characterizing beach changes using SRS & {$[109,110]$} & C \\
\hline & & UAV & - & $\begin{array}{l}\text { Monitoring beach topography and its } \\
\text { change using UAVs imagery }\end{array}$ & [111] & C \\
\hline & Tourism Resort & ARS & & $\begin{array}{c}\text { Estimating the annual carbon budget of } \\
\text { a weekend tourist resort }\end{array}$ & [112] & C \\
\hline \multirow[b]{2}{*}{ Land-Based Industry } & \multirow[t]{2}{*}{ Desalination } & SRS & - & $\begin{array}{l}\text { Characteristics of satellites commonly } \\
\text { used for desalination monitoring }\end{array}$ & [113] & $\mathrm{C} / \mathrm{M}$ \\
\hline & & SRS & MODIS & $\begin{array}{l}\text { Exploring MODIS to assess and monitor } \\
\text { desalination impact }\end{array}$ & [114] & $\mathrm{C} / \mathrm{M}$ \\
\hline \multirow{6}{*}{ Coastal Infrastructures } & Cross-Sea Bridge & SRS & MODIS & $\begin{array}{l}\text { Impact of coastal infrastructure on RS } \\
\text { products using MODIS data }\end{array}$ & [115] & $\mathrm{C} / \mathrm{M}$ \\
\hline & Marina & ARS & - & $\begin{array}{c}\text { Identifying the environmental impact of } \\
\text { a marina development using ARS }\end{array}$ & [116] & $\mathrm{C} / \mathrm{M}$ \\
\hline & \multirow{3}{*}{ Port } & SS & - & $\begin{array}{l}\text { Static Sensors network integration to } \\
\text { estimates harbor activity impact }\end{array}$ & [117] & $\mathrm{C} / \mathrm{M}$ \\
\hline & & SRS & - & $\begin{array}{c}\text { Use of satellite imagery for water quality } \\
\text { studies in New York Harbor }\end{array}$ & [118] & $\mathrm{C} / \mathrm{M}$ \\
\hline & & ARS & & $\begin{array}{l}\text { Assessing the impact of sea-level rise on } \\
\text { port operability using LiDAR-derived } \\
\text { digital elevation models }\end{array}$ & [119] & $\mathrm{C} / \mathrm{M}$ \\
\hline & Beach nourishment & SRS & - & $\begin{array}{l}\text { Sub-annual to multi-decadal shoreline } \\
\text { variability from publicly available SRS }\end{array}$ & [120] & C \\
\hline
\end{tabular}


Table 1. Cont

\begin{tabular}{|c|c|c|c|c|c|c|}
\hline Sector & Type of Activity & $\begin{array}{l}\text { RS technology } \\
\text { SRS, ARS, UAV, } \\
\text { USV, UUV, SS }\end{array}$ & $\begin{array}{c}\text { If SRS Data } \\
\text { Satellite }\end{array}$ & Description/Application & Reference & $\begin{array}{c}\text { Environment } \\
\text { Coastal/Marine }\end{array}$ \\
\hline Navigational Dredging & General & SRS & $\begin{array}{l}\text { Landsat-8 Sentinel-2A } \\
\text { WorldView } 2 \\
\text { WorldView-3 } \\
\text { GeoEye-1 }\end{array}$ & $\begin{array}{l}\text { Assessment of turbidity plumes during } \\
\text { dredging operations using SRS }\end{array}$ & [121] & $\mathrm{C} / \mathrm{M}$ \\
\hline \multirow{2}{*}{ Transport and Shipping } & \multirow{2}{*}{ General } & SRS & Optical Satellite & $\begin{array}{l}\text { Vessel detection and classification using } \\
\text { SRS optical imagery: A literature survey }\end{array}$ & [122] & M \\
\hline & & SRS & SAR & $\begin{array}{l}\text { Maritime Vessel Classification to } \\
\text { Monitor Fisheries with SAR images }\end{array}$ & [123] & $\mathrm{M}$ \\
\hline Renewable Energy & Wind farms & SRS & Radarsat-2 & $\begin{array}{l}\text { Offshore winds mapped from satellite } \\
\text { remote sensing }\end{array}$ & [124] & $\mathrm{M}$ \\
\hline \multirow{3}{*}{ Non-Renewable Energy } & \multirow{2}{*}{$\begin{array}{l}\text { Fossil fuel energy } \\
\text { (Oil/Gas) }\end{array}$} & UUV/USV & - & $\begin{array}{c}\text { Application of robotics in offshore oil } \\
\text { and gas industry }\end{array}$ & [125] & M \\
\hline & & SRS/ARS & $\begin{array}{c}\text { Jers Radarsat-1, Envisat, } \\
\ldots\end{array}$ & $\begin{array}{c}\text { Assessing offshore oil/gas platform } \\
\text { status using SRS and ARS time-series } \\
\text { images }\end{array}$ & [126] & $\mathrm{C} / \mathrm{M}$ \\
\hline & Nuclear energy & SRS & Landsat TM and ETM+ & $\begin{array}{l}\text { Application of SRS data for Monitoring } \\
\text { Thermal Discharge Pollution from a } \\
\text { Nuclear Power Plant }\end{array}$ & [127] & $\mathrm{C} / \mathrm{M}$ \\
\hline $\begin{array}{l}\text { Carbon Capture and } \\
\text { Storage }\end{array}$ & General & SRS/ARS & - & $\begin{array}{l}\text { RS technologies for monitoring geologic } \\
\text { storage operations }\end{array}$ & [128] & C \\
\hline Research and Education & Marine archeology & SRS/ARS & & $\begin{array}{l}\text { ARS and SRS for archaeological and } \\
\text { cultural heritage applications: A review } \\
\text { of the century (1907-2017) }\end{array}$ & [129] & $\mathrm{C} / \mathrm{M}$ \\
\hline Land Reclamation & - & SRS & Sentinal-1 & $\begin{array}{l}\text { Impacts of land reclamation assessed } \\
\text { with Sentinel-1: The Rize (Turkey) }\end{array}$ & [130] & $\mathrm{C} / \mathrm{M}$ \\
\hline \multirow[b]{2}{*}{ Military } & General & SRS & DigitalGlobe \& MODIS & $\begin{array}{c}\text { Evidence of environmental changes } \\
\text { caused by Chinese island-building using } \\
\text { SRS }\end{array}$ & [131] & M \\
\hline & Munition test and use & UUV & - & $\begin{array}{l}\text { Spread, Behavior, and Ecosystem } \\
\text { Consequences of Conventional } \\
\text { Munitions Compounds in Coastal } \\
\text { Marine Waters }\end{array}$ & [132] & M \\
\hline
\end{tabular}




\section{1. $R S$ and Driving Activities}

Remote sensing technologies have transformed research in many sectors related to coastal and marine areas. Table 1 summarizes the recent advanced application of remote sensing in relation to the main activities in key economic sectors in marine and coastal areas (see Figure 1).

\subsubsection{Agriculture}

Agriculture activity is essential for food security. However, agricultural production is considered as the single most extensive form of land use on the planet, occupying more than $40 \%$ of its area [133]. There are many types of agriculture activities that can be found in the coastal zones (e.g., extensive cereal farming and intensive greenhouse farming).

Remote sensing technologies have been a useful tool for assessing agricultural targets, such as the monitoring of soil properties, crop classification, monitoring and crop stress, supporting decisions on irrigation, fertilization, and pest management for production [134]. Recently, [91] reviewed RS data for agricultural landscape monitoring. Liu et al., 2019 [92] analysed the existing issues, latest advances, and future directions in synthetic aperture radar used on agriculture fields as SRS. Fritz et al., 2019 [93] compared eight global and regional agricultural monitoring systems that use RS.

- Coastal Forestry

Coastal forests deliver many benefits, such as preserving biodiversity, conserving water and land resources, carbon storage, storm protection, and many other products [135]. They can be natural or human-made and exist in different forms, such as mangroves, beach forests, peat swamp forests, riparian forests, periodic swamps, and many others. Beitl., 2019 [94] combined Landsat images of 30 years in an analysis to quantify the patterns of cover change of mangrove forest in Ecuador.

- Coastal Farming-Greenhouses

The numbers of plastic-covered greenhouses have been increasing drastically in the last decades, especially in coastal areas, showing the evolution from traditional to industrial farming styles. Their detection and mapping via RS are still a complex task. Arguilat et al., 2015 [88] derived several agricultural features from Landsat 8 and WordView-2 SRS data, which allowed him to detect the four most popular autumn crops in greenhouses in Almeria, Spain. Yang et al., 2017 [87] proposed a new plastic greenhouse index using medium spatial resolution satellite data, such as Landsat Enhanced Thematic Mapper Plus (ETM+) images.

\subsubsection{Livestock}

Livestock rearing is an important activity that contributes to the input of organic matter and nutrients, and its production has increased rapidly in recent decades. UAVs are good tools to estimate livestock. Kellenberger et al., 2018 [95] addressed animal detection through UAVs and used a Convolutional Neural Network to increase the detection of animals located in fields.

\subsubsection{Golf}

Golf practice has increased in popularity during the last decades and the number of golf courses has grown rapidly. This exerts multiple pressures on the environment using fertilizers, pesticide, and water [136]. Based on landscape metrics using multispectral medium-resolution SRS imagery from SPOT 5 images, [96] proposed a practical bottom-up approach to detect golf courses.

\subsubsection{Damming}

Building dams along rivers that end downstream to the coast is increasing with time $[137,138]$. Ezcurra et al., 2019 [139] demonstrated the impact on the physical processes and biodiversity of coastal zones, such as coastal erosion, loss of habitat for fisheries, and the release of carbon sequestrated in 
coastal sediments. Karamvasis et al., 2017 [97] used Sentinel-1 TOPS data through the application of Persistent Scatterer Interferometry methodologies for mapping and measuring dynamic patterns changes of coastal topography in the West Lesvos in Greece, which also showed a reduction in fluvial sediment supply.

\subsubsection{Aquaculture}

Aquaculture is becoming one of the principal sources of aquatic proteins worldwide due to the rise of the human population and the high demand for aquatic protein that can be found inland, the coast, and the sea [140]. It is also a major sector for Blue Growth [141]. There are three types of areas for its cultivation, namely freshwater (lakes, rivers), brackish water (lagoon, estuary), and marine waters (fjords, open water). RS technologies are useful tools for site selection and/or detection and monitoring of aquaculture sites [142]. Ottinger et al., 2016 [98] provided a review of recent studies that used satellite images for the assessment of aquaculture and also presented their potentials and opportunities. Bao et al., 2019 [99] reviewed the latest advances of UUVs and recommended the development of their integrated navigation systems.

Furthermore, aquaculture production includes many types of cultivation systems, such as cages and pens, tanks, ponds, nets, longlines, and intertidal shellfish culture. Bostock et al., 2010 [143] and Troell et al., 2013 [144] provide some examples of cultivation types and the role of RS for their detection and monitoring. However, this excludes pens and longlines as it is still difficult to detect them from long-distance sensors (SRS, ARS, and UVS).

- Tanks

There is an increasing demand for tanks by aquatic industries, which are increasingly getting larger [145], thereby requiring improvements to the monitoring of the conditions for fish culture. Parra et al., 2018 [80] proposed a set of SS using wireless sensor networks in aquaculture tanks for monitoring the water quality and fish behaviour during the feeding procedures.

- Ponds

Ponds have been rapidly expanding during the last decades within fertile coastal zones. SRS can be used to quantitively assess the expansion of the pond's land use and its impact on the coastal environment using satellite images, such as Landsat for long time series analysis [100] and/or Sentinel-1 [146].

- Shellfish Culture

Shellfish culture produces essentially bivalve molluscs, such as oysters, mussels, and clams. Le Bris et al., 2016 [101] used hyperspectral and multispectral data by combining SRS images (TerraSAR-X and SPOT 5) and ARS images (Hyspex) to map wild oysters' reefs and provide an estimation of their stocks.

\subsubsection{Extraction of Living Resources}

Extraction of living resources in marine and coastal areas can be represented in different ways, such as fishing, seaweed harvesting, and saltmarsh vegetation harvesting.

- $\quad$ Fishing

There is a high demand for fish protein, but the productivity of fisheries is in decline worldwide. RS technologies are used for both guiding vessels to locate fishes and monitoring fishing vessels to manage fisheries with the help of SRS, ARS SS, and USVs. Klemas, 2013 [102] reviewed the fisheries application of RS and described their importance and their combination with forecast models on improving the extraction and the management of fisheries resources. Laurs et al., 2006 [147] used SS and USVs connected to the Argos satellite system to tag large pelagic marine fish (tuna, billfish, and sharks). Furthermore, SRS, such as the VIIRS Visible Infrared Imaging Radiometer Suite developed by NASA/NOAA, is a widely used tool for fish detection [148]. 
- $\quad$ Seaweed and Saltmarsh Vegetation Harvesting

Aquatic vegetation support and maintain the ecosystem functions, produce goods and services, and provide many societal benefits. SRS is an important tool for their assessment, detection, as well as monitoring of harvesting activities [103].

\subsubsection{Extraction of Non-Living Resources}

The extraction of non-living resources in different forms on the coast and at seas, such as sand mining and offshore mineral extraction, which are important activities for Blue Growth [141].

- Coastal Sand Mining

This activity provides incomes to contractors and inexpensive materials for the construction industry [149] due to the relatively simple extraction process. Chaussard and Kerosky., 2016 [104] used optical SRS data to identify legal and illegal mining sites in the black sand beach of the Philippines and used Interferometric Synthetic Aperture Radar as SRS to evaluate their environmental impacts.

- Onshore Mineral Extraction

This activity can be found near to the coast and it can impact biodiversity. Werner et al., 2019 [105] reviewed the recent contribution of RS technologies (SRS, ARS, and UAV) to assess the impact on mining extraction.

\subsubsection{Tourism and Recreation}

There is a range of activities on the coast and sea related to tourism and recreation, which can be monitored using RS data such as coastal swimming pool use, beach use, resort construction, and many others.

- Swimming Pools

Swimming pools place extra burdens on local water supply systems and intensify water scarcity. For instance, in coastal rural areas, swimming pools may be using unlicensed boreholes for their water supply. Swimming pools in residential areas can be assessed with different RS data by using SRS, ARS, and UAVs. Llausàs et al., 2018 [108] used LIDAR data as an ARS application from the cadastre of Barcelona city to estimate water use for private swimming pools along the coast of the city. Wolf and Hof., 2012 [107] performed machine learning techniques integrated with high-resolution SRS imagery derived from Worldview 2 data to generate information regarding urban water consumption, including swimming pool assessment.

\section{- $\quad$ Beach Use}

Beach tourism can lead to the degradation of coastal ecosystems. Research on beach use has become more collaborative, with the increased use of RS data and for the protection of natural values of coastal ecosystems $[150,151]$. The high-resolution images of UAVs support topographic surveys and detect geomorphic changes in complex beach terrains. However, there are limitations on data coverage and the loss in vertical accuracy induced by external factors [111]. SRS is largely used for the detection of beach changes. Cabezas-Rabadàn et al., 2019 [109] proposed a new perspective for using Satellite-Derived Shorelines (SDS) from Landsat 8 data to manage microtidal beaches with high tourism influx, such as the case of Valencia, Spain. For the same region, [110] proposed a detailed characterization of beach changes using SDS derived from Sentinel-2 data as an automatic, massive, and efficient shoreline extraction tool to derive beach width as an indicator of beach morphology.

- $\quad$ Tourist Resort 
Many tourist operators focus on providing a large number of activities inside and outside their buildings, to retain a large number of tourists in the resort by meeting their vacation needs. Such a concentration of numbers and activities in a small area presents management challenges similar to that of a small town [152]. Sung et al., 2015 [112] used ARS images to estimate the annual carbon budget from emission and sequestration of a weekend tourist resort in Korea by using LIDAR data combined with visitor surveys and energy consumption data.

Furthermore, Miller et al., 2018 [106] provided an overview of the benefits of RS data for supporting the sustainability of Protected Destination Systems (PDSs) as ecological touristic spaces that can be taken as good practices in coastal tourism.

\subsubsection{Land-Based Industry}

Many types of industries can be found in coastal areas, especially in the vicinity of ports. Industrial activities produce several environmental and socio-economic impacts that can be analysed using RS technologies by assessing their effluents and use of resources from land, fresh, and marine waters. There has been an unprecedented increase in desalination plants to meet the global demand for water.

- Desalination

The plants are broadly distributed along coastlines worldwide. The common impacts of their effluent are water intakes, sea outfall discharges, and harmful algal blooms that can be detected and monitored through the potential use of RS. For a large-scale area, [114] used MODIS visible and thermal channels as an SRS application to assess the impact in the Arabian Gulf. Al Shehhi et al., 2017 [113] provided a list of satellites commonly used in ocean colour applications and their characteristics, and [153] presented a guide to the management of desalination impacts.

\subsubsection{Coastal Infrastructure}

Coastal infrastructure refers to structures built along coastlines, such as cross-sea bridges in regional seas (e.g., Øresund bridge), marinas, ports, seawalls, groynes, jetties, piers, and many others.

\section{- Cross-Sea Bridges}

This type of infrastructure can bring huge benefits to the connected regions for social and economic development, but also create an environmental impact. Yuan et al., 2019 [115] showed the impact of these infrastructures on ocean colour RS data by using MODIS images.

\section{- Marinas}

The increase of these coastal infrastructures has accelerated in the late 20th century and early 21st century along all coastlines of the world. Klein et al., 2001 [116] provided an approach to assessing marina development and showed their impact on adjacent beaches using ARS images.

- $\quad$ Ports

In particular, shipping ports are important transport hubs in the global supply chain of goods. Building such infrastructure attracts investors and there is an increasing competition between countries and regions for the deep-water "Panamax" ports that are needed for giant or mega container ships, or Very Large Crude Carriers (VLCC). Merico et al., 2019 [117] presented a network approach for low-cost static sensors (SS) that operates in near-real-time data to assess shipping traffic impact and harbour-related activities with a major concern for air quality. SRS can support the assessment of water quality related to harbours despite the complexity of their hydrography and the influence of tides. Hellweger et al., 2004 [118] compared different SRS images using time-averaged spatial analysis to assess many parameters related to the impact of New York Harbor. ARS hyperspectral images can also support monitoring of water quality in harbours [154]. Furthermore, [119] deployed ARS using LiDAR-derived digital elevation to assess port infrastructure and its operability under scenarios of sea-level rise. 


\section{- $\quad$ Beach Nourishment}

Nourishment of beaches with sand is used to reduce coastal erosion $[155,156]$ and to attract tourists [157]. Vos et al., 2019 [120] assessed different sandy beaches from different parts of the world to quantify the changes in shorelines using different accessible, free SRS data combined with in situ data, and provided a list of major civilian satellites to measure the impact of this activity.

\subsubsection{Navigational Dredging}

Shipping activities involve dredging operations to maintain navigational access and this can contribute to the loss of habitat, due both to the removal of substrates and to lethal or sublethal stress caused by elevated sedimentation and turbidity [158]. There are also large areas where the dredged sediments may be stored, especially if they are contaminated. Many SRS-based approaches have been used to assess the impacts. Caballero et al., 2018 [121] combined five public and commercial mediumand high-resolution satellites that allowed cost-effective monitoring of turbidity plumes during dredging processes, including WorldView-2, WorldView-3, Landsat-8, Sentinel-2A, and GeoEye-1 SRS.

\subsubsection{Transport and Shipping}

The maritime transport and shipping sectors have shown an exponential increase in the number of vessels used to transport people and goods crossing different seas around the world [159]. Kanjir et al., 2018 [122] presented a literature survey of 30 years of research on ship detection and classification using optical SRS imagery and presented positive and negative aspects of each type of detection method, which allowed them to predict future trends for this area of SRS applications. Xiao et all., 2018 [123] used SAR images (SRS) to distinguish between fishing and non-fishing vessels based on the Random Forest approach in order to tackle overfishing issues.

\subsubsection{Renewable Energy}

Renewable energy may be generated in different ways, namely offshore wind, tides, ocean currents, and waves. Wind farms are the most common [160]. They have been growing due to the environmental conditions along the coasts and in the sea [161]. However, the installation of offshore wind farms and their operation can degrade the sea floor and create artificial reefs. Their impact on the sustainability of the sea needs to be assessed [162]. Hasager, 2014 [124] showed the potential of high-resolution SAR data from RADARSAT-2 SRS to map offshore wind farms and to detect wakes from long and far-field wind farms.

\subsubsection{Non-Renewable Energy}

- Fossil Fuels (Oil and Gas)

Offshore oil and gas operations present various environmental hazards due to drilling and spills, as well as major accidents [163]. RS technologies can help to avoid both human and environmental threats. Shukla and Karki, 2016 [125] reviewed the application of USVs and UUVs to survey offshore sites, an inspection that requires remote assistance as well as surveillance for preventing and cleaning up oil spills. Liu et al., 2018 [126] used a time-series RS approach to assess offshore oil and gas platforms status by combining 26,000 SRS and ARS images from JERS, RADARSAT-1, ENVISAT, ALSO (PALASAR), Landsat Collection, and (S-NPP) VIIRS SRS, as well as from the National Agriculture Imagery Program (NAIP) aerial images. This approach detected 9260 platforms and determined installation and removal dates.

\section{- Nuclear Power}

Nuclear power plants are often located on coasts to use the seawater for cooling. This entails some risks, such as the 2011 Fukushima Daiichi accident after a tsunami caused by the Sendai earthquake in Japan. However, many others are at risk from erosion, rising sea-levels, and storm surges; a well-known 
example being Hinkley Point in the UK. Nevertheless, normal operation causes thermal discharge pollution that has a significant impact on the coastal environments and marine ecosystems [164]. Dai et al., 2012 [127] used a multi-temporal Landsat band six thermal infrared SRS images to assess the spatial diffusion of thermal discharge and to quantify the variability of sea surface temperatures.

\subsubsection{Carbon Capture and Storage}

Carbon capture and storage (CCS) is one option to reduce the $\mathrm{CO}_{2}$ from emissions. There is growing interest and investment, but there are uncertainties with respect to adapted technologies, engineering performance, and natural hazards [165]. The U.S. Department of Energy, National Energy Technology Laboratory, has developed many applications of RS technologies to monitor storage operations, including SRS, ARS (LiDAR), and USV [128] to assess CCS. The full list of technologies is provided by [128].

\subsubsection{Marine Archaeology}

Marine archaeologists have identified several marine archaeological sites, especially with the use of RS technologies such as SRS and UUVs to detect the objects and features of these sites [166-168]. Luo et al., 2019 [129] reviewed a century of SRS and ARS applications for archaeological research, including the coast and the sea.

\subsubsection{Land Reclamation}

Land-use change and reclamation of coastal areas have increased due to increasing pressure in the coastal zone, especially for agriculture, aquaculture, urbanization, industrial plants, infrastructure such as airports, and even artificial islands [169]. Martin-Anton et al 2016 [170] assessed the world's land reclamation situation using Google Earth and showed that the highest development exists in East Asian countries (China, Japan, and Korea). Zhang et al., 2017 [171] focused especially on the South China Sea, using SRS from Landsat to assess the situation between 1975 and 2010. Pressures from land reclamation activities lead to environmental change and degradation of coastal natural habitats, such as wetlands and dunes. RS can be used to measure changes and monitor reclaimed land and coastline length [172-174]. Erten and Rossi, 2019 [130] used SRS from Sentinel-1 images to detect and assess subtle land displacements to monitor small areas with high risk.

\subsubsection{Military}

For the military, mostly the Navy, infrastructure on the coast is growing due to being strategically important, and recently many new structures have been revealed through satellite images. Smith et al., 2019 [131] presented evidence of environmental changes from a military base built on artificial islands on the South China Sea by using SRS data from DigitalGlobe and MODIS images. Furthermore, another issue resulting from military activities in coastal marine environments is the intentional disposal of unexploded ordnance and munitions that contain organic explosives and a variety of metals. These can be assessed by RS technologies (USV and UUV) using Multibeam sonar, sub-bottom profiling, and magnetometry [132].

\subsection{RS and Pressures}

The increasing influence of human activities on the coast and the ocean leads to a variety of anthropogenic pressures combined with natural pressures, which make them hotspots of global change [36,175]. Recent advances in remote sensing technologies (RS) can help in mapping and assessing the pressures. Table 2 summarizes the recent advanced application of RS in relation to the main pressures that can be found in marine and coastal areas and their usefulness regarding WFD indicators, MSFD descriptors, UN SDGs targets, and OHI goals. 
Table 2. A review of the remote sensing applications that are being developed for each pressure related to coastal and marine areas.

\begin{tabular}{|c|c|c|c|c|c|c|c|c|c|c|}
\hline Pressures & Sub- Pressures & $\begin{array}{l}\text { RS technology } \\
\text { SRS, ARS, UAV, } \\
\text { USV, UUV, SS }\end{array}$ & $\begin{array}{l}\text { If SRS Data } \\
\text { Satellite }\end{array}$ & Description/Application & Reference & $\begin{array}{l}\text { Environment } \\
\text { Coastal/Marine }\end{array}$ & $\begin{array}{c}\text { WFD } \\
\text { Indicators }\end{array}$ & $\begin{array}{c}\text { MSFD } \\
\text { Descriptors }\end{array}$ & $\begin{array}{c}\text { UN } \\
\text { SDG } \\
\text { Targets }\end{array}$ & $\begin{array}{l}\text { OHI } \\
\text { Goals }\end{array}$ \\
\hline $\begin{array}{l}\text { Nutrient } \\
\text { Enrichment }\end{array}$ & General & SRS & GOCI/SMAP & $\begin{array}{l}\text { Satellite Retrieval of Surface Water Nutrients in } \\
\text { Coastal Region }\end{array}$ & [89] & $\mathrm{C} / \mathrm{M}$ & $\mathrm{BQE}$ & D5 & $\begin{array}{c}\text { T3.9 } \\
\text { T6.3 } \\
\text { T14.1 }\end{array}$ & G1-10 \\
\hline \multirow[b]{2}{*}{$\begin{array}{l}\text { Underwater } \\
\text { Noise }\end{array}$} & \multirow[b]{2}{*}{ General } & ARS & - & Optical remote sensing of sound in the ocean & [176] & $\mathrm{M}$ & & \multirow{2}{*}{ D11 } & \multirow{2}{*}{ T14.4 } & \\
\hline & & SS & - & $\begin{array}{l}\text { Baseline assessment of underwater noise in the } \\
\text { Ria Formosa using SS }\end{array}$ & {$[177]$} & $\mathrm{C} / \mathrm{M}$ & & & & \\
\hline \multirow[t]{3}{*}{$\begin{array}{l}\text { Death and } \\
\text { Injury }\end{array}$} & General & SRS & Landsat/MODIS & $\begin{array}{l}\text { Extensive coral mortality and critical habitat loss } \\
\text { following dredging and their association with RS } \\
\text { of sediment plumes }\end{array}$ & [178] & $\mathrm{C} / \mathrm{M}$ & BQE & $\begin{array}{l}\text { D1 } \\
\text { D3 } \\
\text { D6 }\end{array}$ & $\begin{array}{l}\text { T14.4 } \\
\text { T14.5 } \\
\text { T12.2 }\end{array}$ & $\begin{array}{c}\text { G1-8 } \\
\text { G10 }\end{array}$ \\
\hline & General & - & - & $\begin{array}{l}\text { Toward the Integrated Marine Debris Observing } \\
\text { System (IMOS) }\end{array}$ & [179] & $\mathrm{C} / \mathrm{M}$ & & \multirow{7}{*}{ D10 } & \multirow{7}{*}{ T14.1 } & \multirow{7}{*}{ G6-10 } \\
\hline & $\begin{array}{c}\text { Macro plastics } \\
\text { on the ocean }\end{array}$ & ARS & - & $\begin{array}{l}\text { Sensing ocean plastics with an airborne } \\
\text { hyperspectral shortwave infrared imager }\end{array}$ & [180] & M & & & & \\
\hline \multirow{5}{*}{$\begin{array}{l}\text { Presence of } \\
\text { Marine Litter }\end{array}$} & \multirow{5}{*}{$\begin{array}{l}\text { General Marine } \\
\text { Litter }\end{array}$} & \multirow{3}{*}{ UAV } & - & $\begin{array}{l}\text { Monitoring of beach litter by automatic } \\
\text { interpretation of UAV images using the } \\
\text { segmentation threshold method }\end{array}$ & [181] & C & & & & \\
\hline & & & - & $\begin{array}{l}\text { Use of UAV for efficient beach litter monitoring } \\
\text { using a beta version of a machine learning tool }\end{array}$ & [182] & C & & & & \\
\hline & & & - & $\begin{array}{l}\text { Anthropogenic marine debris assessment with } \\
\text { UAS imagery and deep learning }\end{array}$ & [183] & $\mathrm{C}$ & & & & \\
\hline & & SRS & WorldView 3 & $\begin{array}{l}\text { Anthropogenic marine debris over beaches: } \\
\text { Spectral characterization for SRS application }\end{array}$ & [184] & $\mathrm{C} / \mathrm{M}$ & & & & \\
\hline & & ARS & - & $\begin{array}{l}\text { Mapping coastal marine debris using ARS } \\
\text { imagery and spatial analysis }\end{array}$ & [185] & $\mathrm{C} / \mathrm{M}$ & & & & \\
\hline $\begin{array}{l}\text { Substratum } \\
\text { Loss }\end{array}$ & - & ARS/SRS & WorldView 2 & $\begin{array}{l}\text { Automating nearshore bathymetry extraction } \\
\text { from wave motion in satellite optical imagery }\end{array}$ & [186] & $\mathrm{M}$ & $\mathrm{HQE}$ & D6 & T14.4 & $\begin{array}{l}\text { G1-5 } \\
\text { G7-8 } \\
\text { G10 }\end{array}$ \\
\hline $\begin{array}{l}\text { Coastal } \\
\text { Erosion }\end{array}$ & General & SRS & (Optical SRS) & $\begin{array}{l}\text { Shoreline Detection using Optical Remote } \\
\text { Sensing: A Review }\end{array}$ & [187] & $\mathrm{C}$ & & D7 & $\begin{array}{c}\text { T14.2 } \\
\text { T9.1 } \\
\text { T11.1 } \\
\text { T11.5 } \\
\end{array}$ & G5, \\
\hline Change in & General & SRS & Landsat 8 OLI & $\begin{array}{l}\text { Remotely sensed sea surface salinity in the } \\
\text { hyper-saline Arabian Gulf: Application to } \\
\text { Landsat } 8 \text { OLI data }\end{array}$ & [188] & $\mathrm{C} / \mathrm{M}$ & PCQE & D7 & T14.1 & \\
\hline Salinity & & SRS & Aquarius & Assessment of Aquarius Sea Surface Salinity & [189] & $\mathrm{C} / \mathrm{M}$ & & & & \\
\hline & Hydrocarbons & SRS & - & A Review of oil spill remote sensing & [190] & $\mathrm{C} / \mathrm{M}$ & & & T6.3 & \\
\hline $\begin{array}{l}\text { Introduction } \\
\text { of Synthetic }\end{array}$ & & UAV & - & $\begin{array}{c}\text { Distributed operation of collaborating UAVs for } \\
\text { time-sensitive oil spill mapping }\end{array}$ & [191] & $\mathrm{C} / \mathrm{M}$ & PCQE & D8 & $\begin{array}{l}\text { T14.1 } \\
\text { T3.3 }\end{array}$ & G1-10 \\
\hline Compounds & Toxic metal & SRS & Landsat & $\begin{array}{l}\text { Assessment ecological risk of heavy metal using } \\
\text { SRS }\end{array}$ & [192] & $\mathrm{C}$ & & & T3.9 & \\
\hline
\end{tabular}


Table 2. Cont.

\begin{tabular}{|c|c|c|c|c|c|c|c|c|c|c|}
\hline Pressures & Sub- Pressures & $\begin{array}{l}\text { RS technology } \\
\text { SRS, ARS, UAV, } \\
\text { USV, UUV, SS }\end{array}$ & $\begin{array}{l}\text { If SRS Data } \\
\text { Satellite }\end{array}$ & Description/Application & Reference & $\begin{array}{l}\text { Environment } \\
\text { Coastal/Marine }\end{array}$ & $\begin{array}{l}\text { WFD } \\
\text { Indicators }\end{array}$ & $\begin{array}{c}\text { MSFD } \\
\text { Descriptors }\end{array}$ & $\begin{array}{c}\text { UN } \\
\text { SDG } \\
\text { Targets }\end{array}$ & $\begin{array}{l}\text { OHI } \\
\text { Goals }\end{array}$ \\
\hline \multirow{3}{*}{$\begin{array}{l}\text { The Input of } \\
\text { Organic Matter }\end{array}$} & Organic Matter & SRS & Landsat & $\begin{array}{l}\text { SRS data from Landsat to estimate organic matter } \\
\text { distribution }\end{array}$ & [193-195] & $\mathrm{C} / \mathrm{M}$ & \multirow{3}{*}{ PCQE } & \multirow{3}{*}{ D5 } & T6.3 & \multirow{3}{*}{ G1-10 } \\
\hline & \multirow{2}{*}{$\begin{array}{l}\text { Dissolved } \\
\text { Organic Matter } \\
\text { (DOM) }\end{array}$} & \multirow{2}{*}{ SRS } & MERIS L1 & $\begin{array}{l}\text { DOM at the fluvial-marine transition in using in } \\
\text { situ data and ocean color RS }\end{array}$ & [196] & $\mathrm{C} / \mathrm{M}$ & & & $\begin{array}{l}\mathrm{T} 14.1 \\
\mathrm{~T} 3.3\end{array}$ & \\
\hline & & & MODI/Aqua & $\begin{array}{l}\text { Long-term changes in colored DOM from SRS } \\
\text { data from MODIS }\end{array}$ & [197] & $\mathrm{M}$ & & & $\begin{array}{l}1.0 . \\
\mathrm{T} 3.9\end{array}$ & \\
\hline \multirow{3}{*}{$\begin{array}{c}\text { Input } \\
\text { ofRadionuclides }\end{array}$} & \multirow{3}{*}{ General } & - & - & $\begin{array}{l}\text { RS radiation mapping: overview and application } \\
\text { of current and future aerial systems }\end{array}$ & [198] & C & \multirow{3}{*}{ PCQE } & \multirow{3}{*}{ D8 } & T6.3 & \multirow{3}{*}{ G9 } \\
\hline & & SRS/ARS & Landsat & $\begin{array}{l}\text { Distribution of radioactive black sand along a } \\
\text { coastal area using ARS and SRS }\end{array}$ & [199] & C & & & $\begin{array}{l}\text { T14.1 } \\
\text { T3.3 }\end{array}$ & \\
\hline & & UAV & - & $\begin{array}{l}\text { Radiological Assessment on Interest Areas on the } \\
\text { Sellafield Nuclear Site via Unmanned Aerial } \\
\text { Vehicle }\end{array}$ & [200] & C & & & $\begin{array}{l}13.3 \\
\mathrm{~T} 3.9\end{array}$ & \\
\hline $\begin{array}{l}\text { Thermal } \\
\text { Pollution }\end{array}$ & General & SRS & $\begin{array}{l}\text { Landsat } \\
\text { HJ-1B } \\
\text { MODIS }\end{array}$ & $\begin{array}{l}\text { Detection of thermal pollution from power plants } \\
\text { on China's eastern coast using remote sensing } \\
\text { data }\end{array}$ & [201] & $\mathrm{C} / \mathrm{M}$ & PCQE & D7 & $\begin{array}{c}\text { T14.1 } \\
\text { T14.3 } \\
\text { T3.3 } \\
\text { T3.9 }\end{array}$ & $\begin{array}{l}\text { G2-8 } \\
\text { G10 }\end{array}$ \\
\hline
\end{tabular}


For WFD, there are three main indicators: Biological Quality Elements (BQE), Physico-Chemical Quality Elements (P-CQE), and Hydromorphological Quality Elements (HQE) (see https://ec.europa. eu/environment/water/water-framework/index_en.html).

For MSFD, there are eleven related descriptors: D1—biological diversity; D2—non-indigenous species; D3-fisheries; D4-food webs; D5-eutrophication; D6-seafloor integrity; D7-hydrographical conditions; D8—contaminants; D9—contaminants in seafood; D10—marine litter; and D11—energy and noise (see https://ec.europa.eu/environment/marine/eu-coast-and-marinepolicy/marine-strategy-framework-directive/index_en.htm).

For the SDGs, there are seventeen goals: SDG1-no poverty; SDG2-zero hunger; SDG3—good health and well-being; SDG4-quality education; SDG5-gender equality; SDG6-clean water and sanitation; SDG7-affordable and clean energy; SDG8-decent work and economic growth; SDG9-industry, innovation, and infrastructures; SDG10—reduced inequality; SDG11—sustainable cities and communities; SDG12 - responsible consumption; SDG13 — climate action; SDG14-life below water; SDG15-life on land; SDG16 - peace justice and strong institutions; and SDG17—partnerships for the goals. Furthermore, each goal has specifics targets (e.g., T14.1 is the first target of SDG 14, and T6.3 is the third target of SDG 6).

For OHI, there are ten goals: G1-food provision; G2-artisanal fishing opportunities; G3-natural products; G4-carbon storage; G5-coastal protection; G6-tourism and recreation; G7-coastal livelihoods and economies; G8 - sense of place; G9-clean waters; and G10—biodiversity. Furthermore, each goal has specific components (http://www.oceanhealthindex.org/methodology/ goals). Some components can occur in more than one goal (e.g., nutrient pollution).

The findings show which approach could be followed to assess a specific pressure found in one of the environmental indicators, descriptors, targets, or/and goals. For instance, an environmental engineer working on nutrient enrichment assessments could follow the application made by [89] and related frameworks (see Table 2).

\subsubsection{Nutrient Enrichment}

Activities related to agriculture and animal rearing, including aquaculture, urban sewage, and transport, introduce nutrients to coastal waters through diffuse run-off, atmospheric deposition, and point-sources of effluents. Increasing nitrate and phosphate loads on the coastal and marine environment can lead to eutrophication, phytoplankton, and algal blooms [201,202]. These pressures affect the function of aquatic ecosystems and lead to the decline of marine habitats. RS monitoring approaches can offer high-frequency and large-scale observation to assess nitrate and phosphate as important water quality indicators. Wang et al., 2018 [89] used SRS images from GOCI and SMAP satellites together with sea surface salinity and remote-sensing reflectance models that enabled them to obtain long time-series variation in nitrate and phosphorus concentration. MODIS, MERIS, Landsat, and SeaWiFS SRS images can be used for short-term detection. Furthermore, [203] provided a model derived from satellite-sensed components, such as sea surface temperature, chlorophyll, and others, to estimate a global monthly nitrate concentration at the sea surface.

\subsubsection{Underwater Noise}

Human activities, such as maritime transport, fishing, geophysical exploration, and dredging, increase the pressure of underwater noise by generating a sound that causes negative impacts on marine life. This pressure can be amplified in shallow water, such as lagoons $[4,177]$. Churnside et al., 2014 [176] suggested theoretical approaches that use ARS images (i.e., LiDAR) to measure sound in the upper ocean by modelling natural bubbles near the sea surface. Soares et al., 2019 [177] used the RS approach based on SS hydrophone (called digitalHyd SR-1) to record the noise between summer and winter in the Ria Formosa lagoon in Portugal. 


\subsubsection{Death and Injury}

Death and injury pressures on marine organisms can be posed by several activities, such as smothering or dredging materials. Cunning et al., 2019 [178] used SRS data from MODIS and Landsat images to identify sediment plumes in the port of Miami and to quantify its effect on coral mortality and critical habitat loss. This was combined with in situ data to reliably evaluate the magnitude and extent of the area affected by the dredging activity.

\subsubsection{Presence of Marine Litter}

The issue of marine litter, especially marine plastic, has been highly visible on all media types and has focused public concerns on this type of pollution as an important societal problem. Efforts to tackle marine litter have focused on the management aspect, rather than monitoring pressures [204,205].

There are many types of debris that can be found on the coast and the sea, including microplastics, as well as many other wastes. RS applications to marine litter are still in their early stages, but present a great potential to provide global monitoring with extensive coverage and long-term assessment [206].

\section{- $\quad$ General Marine Litter}

Different RS technologies can be applied to assess marine litter from space (SRS, ARS, and UAV). UAVs are the most used, as they are 39 times faster than a visual census [182]. The segmentation threshold method, using statistical information of image histograms, is considered a suitable approach for extracting targets from UAV images [181]. Fallati et al., 2019 [183] combined UAV images with deep-learning-based software to confirm the efficiency of UAVs as tools for monitoring and to demonstrate the potential of deep learning for automatic detection. Martin et al., 2018 [182] used a beta version of the machine learning tool. Furthermore, ARS and SRS have been used to collect marine litter information. Moy et al., 2018 [185] used high-resolution SRS imagery for automatic digital classification of marine litter. From an assessment of three beaches, the images were integrated with hyperspectral laboratory measurements that showed an overall accuracy equivalent to $88 \%$ with detection of over 50 tons of debris. Moy et al., 2018 [185] provided precise macro-debris $\left(>0.05 \mathrm{~m}^{2}\right)$ measurements to identify 20,658 debris items with their location, type, and size along $1600 \mathrm{~km}$ of coastline in the Huawei island by using ARS images; plastics comprised $83 \%$ of the total count.

At a regional scale, a beach litter database for the European sea (under the EMODnet initiative) has been developed by the European Commission (JRC), HELCOM, OSPAR, and the MSFD marine litter group by assessing 518 beaches from 29 countries, including SRS surveys [207].

Moreover, [179] suggested a conceptual model of an Integrated Marine Debris Observing System (IMDOS) to monitor changes and distribution of marine debris dynamics by providing a global coverage and precision by using RS data (SRS, ARS, UAV, USV, and SS) and in situ data in order to mitigate the impacts effectively.

- Marine Plastic

The plastics eventually accumulate in the five ocean gyres, forming garbage patches that are so large that they are visible from space. The plastic particles can be detected through RS images. Garaba et al., 2018 [180] used ARS hyperspectral shortwave infrared images to separate marine litter from surrounding seawater using the unique absorption features of the polymer identification technique. Goddijn-Murphy et al., 2018 [208] presented a concept of the spectral model of a hyperspectral RS algorithm that calculates sea surface plastic litter and concluded that it could be visible with spectral light reflectance measurements. A comprehensive SWIR (Short Wave Infrared) spectral signature library for oceanic plastics is in progress. 


\subsubsection{Substratum Loss}

Substratum is important for benthic and demersal species that live associated with the bottom habitat, and sea-floor integrity is a descriptor of marine environmental status (D6 of MSFD). RS can assess the substrates, especially in shallow water. An indirect method to evaluate the bottom is to assess the evolution of water depth. Mancini et al., 2012 [186] compared ARS data using Lidar with SRS data derived from Worldview2 to analyse the sea depth and demonstrated a low relative error between both datasets.

\subsubsection{Coastal Erosion}

Anthropogenic activities, such as the use of sand for urbanization, dredging, and building coastal infrastructure, may lead to coastal erosion pressures and the displacement of the shoreline by natural forces from waves and currents. Toure et al., 2019 [187] presented a state-of-the-art review on the image processing methods using optical SRS for shoreline detection. This includes a summary of shoreline indicators, a list of segmentation, and edge detection approaches.

\subsubsection{Change in Salinity}

Salinity can change due to natural and/or human factors, and RS can be used to assess these changes. Satellite colour imagery (SRS) can be used to measure salinity.

Soil Moisture and Ocean Salinity (SMOS) was the first mission to measure global Sea Surface Salinity (SSS) from space and which started in 2009. Then, it was followed by the Aquarius mission in 2011, which experienced a power failure and stopped working in 2015. The measurement of SSS has been further enhanced after the launch of the Soil Moisture Active-Passive (SMOS) mission in 2015 that provided improved spatial and temporal resolutions compared to previous methods [209]. However, all these missions presents large discrepancies that can be found in high latitudes and in the regions along the coast [209].

Furthermore, different alternatives were developed to improve the salinity data products. For instance, algorithms were used to convert data from the absorption of coloured dissolved organic matter that can be retrieved into salinity units [210].

Statistical approaches, such as multi-linear regression, neural networks, least square regression, and the Box-Jenkins algorithm [188], can also be used to measure radiance or reflectance correlated with salinity. Zhao et al., 2017 [188] used SRS from Landsat 8 OLI data to assess sea surface salinity in the hyper-saline Arabian Gulf while [189] used the SRS image from Aquarius satellite data to measure the salinity.

\subsubsection{Input of Synthetic Compounds: Hydrocarbons}

Increased activities on the coast and at sea, such as offshore oil and gas platforms, transport and shipping, as well as urban runoff, have increased the risk of pollution and contamination from synthetic compounds, hydrocarbons (oil and gas), and metals. RS data have played an important role in assessing oil spills, which are a major environmental concern that can have dramatic consequences [211-213].

SAR (SRS) data can be used to detect oil spills; nevertheless, they are limited in their capacity to separate mineral oil from natural, biogenic films [213], because of noise in the signal. Moreover, there are challenges due to the oil slick thickness that have been poorly studied [214]. A review of oil spill remote sensing is presented by [190] where radar (SRS) is the dominant approach for mapping oil spills. Odonkor et al., 2019 [191] established a distributed approach (called PSOil) to map offshore oil spills using a collaborating team of UAVs. 


\subsubsection{Input of Non-Synthetic Compounds: Toxic Metals}

Human activities from industries, agriculture, transport and ports, as well as sewage effluent increase the pressure of metal contamination and pollution on the coastal and marine environment. Metals are non-biodegradable and some are toxic, as well as accumulating in sediments and biota, presenting a serious environmental problem [215].

Zhu et al., 2017 [192] used SRS data from Landsat images to assess the risk of heavy metals in a coastal area that was affected by high-intensity land reclamation.

\subsubsection{Input of Organic Matter}

Anthropogenic activities, such as the input of sewage effluent and manure, paper mills, and food processing, increase the pressure of organic matter inputs into coastal and marine ecosystems, and can result in reduced water quality and ecosystem health [216]. Organic matter can be either particulate (POM) or dissolved (DOM). DOM can also come from natural processes, such as fluvic and humic acids. Once in the aquatic system, it becomes a dissolved organic matter [217]. Therefore, the Coloured Dissolved Organic Matter (CDOM), which is an optically active subset of DOM, is considered as an important tracer of effluent plumes in coastal waters [218]. Aurin et al., 2012 [219] presented limitations and advantages of ocean colour RS for detecting the CDOM.

RS images have been deployed in many research studies to estimate the organic matter in coastal and marine environments. Wang et al., 2018, Han et al., 2019 and Zan, 2019 [193-195] used SRS data from Landsat images using different approaches to estimate soil organic matter for different coastal ecosystems. Juhls et al., 2019 [196] used SRS data from MERIS L1 satellite scenes to test the statistical performance of five ocean colour remote sensing algorithms and to evaluate the credibility of the spatial distribution of the derived DOM at a fluvial-marine transition area. Cao et al., 2018 [220] used new RS algorithms with a multiple linear regression approach that was developed for retrieving CDOM quality across an estuary ecosystem and that were developed from MERIS/MODIS data.

Long-term changes in CDOM have been presented by [123] using (MODIS)/Aqua products to understand the biogeochemical properties of water bodies and their dynamics.

\subsubsection{Input of Radionuclides}

Radionuclides (e.g., 238U, 232Th, and 40K) naturally occur on the coast and at sea due to geological processes. Examples are the black sand beaches of Kerela (India) and estuaries in uranium-rich catchments, e.g., Figueira da Foz, Portugal. Anthropogenic activities, such as inputs from a nuclear power plant, can further contaminate sediments [221], sometimes over long distances, such as atmospheric deposition from Chernobyl on West European systems.

An overview of current and future aerial system applications to map radiation is discussed by [197]. A gamma-ray spectrometer is generally used to detect, identify, and classify radionuclides [222] and to identify the sources. Gamma-ray spectrometers can be used on RS devices, such as ARS, UAV, or SRS. Kaiser et al., 2014 [198] used ARS gamma-ray spectrometry and SRS from Landsat to measure radioactive abundance along the Rosetta coast (Egypt). They found high concentrations of potassium and a high relative abundance of uranium and thorium due to fertilizer application on cultivated land in the Nile Delta. Martin et al., 2016 [199] deployed a lightweight radiation detection system on a UAV to measure the distribution of radiation with a high accuracy, spatial resolution, and sensitivity for the assessment of a nuclear site in England. 


\subsubsection{Thermal Pollution}

Power plant activities discharge cooling water, causing thermal pollution pressure on the coastal waters that can be assessed by measuring the water temperature distribution [223]. This is difficult and expensive through in situ measurement, making RS technologies an excellent tool for this purpose.

Ma et al., 2017 [200] used a combination of SRS data from Landsat (ETM+), HJ-1B, and Terra (MODIS) satellites to compare sea surface temperature before and after an operating nuclear power plant in the coastal area of China and detected a rise of more than $3{ }^{\circ} \mathrm{C}$ at approximately $17 \mathrm{~km}$.

\subsection{RS and State Changes}

The pressures from human activities cause state changes in the environment, especially the physio-chemical variables and biological quality elements $[7,202]$. These are also relevant to several environmental policies, such as the WFD and the MSFD. These variables will be described one by one in this section.

Recent advances in RS technologies can quantify and assess the environmental state changes. Table 3 summarizes the recent advanced application of RS in relation to the state changes on the environment that can be found in marine and coastal systems.

\subsubsection{Water Quality}

Combining in situ and RS data for water-quality monitoring allows a holistic analysis that can provide alternative management scenarios [243]. Coastal and ocean monitoring are challenging due to multiple sources that modify physico-biological processes [244]. Gholizadeh et al., 2016 [224] presented a review of the commonly employed SRS and ARS to investigate and identify eleven water-quality parameters. A list of sensors for water assessment was presented, including a scan system, type, resolution, spectral range, number of bands, and imaging swath. Furthermore, a list of spectral bands combination and their ratios to assess some parameters is presented as well.

Shang et al., 2018 [245] presented state-of-the-art technology of RS platforms and their sensors that are used for monitoring water quality status and ecosystem state in relation to the nutrient cycle.

\subsubsection{Water Turbidity}

RS images can be used for understanding the temporal turbidity changes and sediment dynamics in coastal systems. Choi et al., 2012 [225] showed the effectiveness of using RS data from the Geostationary Ocean Colour Imager (GOCI) for monitoring the temporal dynamics of coastal water turbidity.

\subsubsection{Suspended Particulate Matter}

In coastal waters, geostationary satellite ocean colour daily data is used to map the dynamics of suspended particulate matter. SRS image from GOCI provides hourly observations that can successfully map SPM in different areas, even in highly dynamic coastal waters [226]. Shang and Xu, 2015 [246] used the atmospheric correction algorithm (UV-AC) from GOCI images, a method developed by [226] and it has been validated with in situ data that showed its potential in coastal turbidity waters. 
Table 3. A review of the remote sensing applications that are being developed for each state change related to coastal and marine areas.

\begin{tabular}{|c|c|c|c|c|c|c|c|c|c|c|}
\hline State Changes & $\begin{array}{c}\text { Sub-State } \\
\text { Changes }\end{array}$ & $\begin{array}{l}\text { RS technology } \\
\text { SRS, ARS, UAV, } \\
\text { USV, UUV, SS }\end{array}$ & $\begin{array}{c}\text { If SRS Data } \\
\text { Satellite }\end{array}$ & Description/Application & Reference & $\begin{array}{l}\text { Environment } \\
\text { Coastal/Marine }\end{array}$ & $\begin{array}{c}\text { WFD } \\
\text { Indicators }\end{array}$ & $\begin{array}{c}\text { MSFD } \\
\text { Descriptors }\end{array}$ & $\begin{array}{c}\text { UN } \\
\text { SDG } \\
\text { Targets }\end{array}$ & $\begin{array}{l}\text { OHI } \\
\text { Goals }\end{array}$ \\
\hline Water Quality & General & $\begin{array}{l}\text { SRS } \\
\text { ARS }\end{array}$ & - & $\begin{array}{l}\text { A Comprehensive review on water quality } \\
\text { parameters estimation using RS techniques }\end{array}$ & [225] & $\mathrm{C} / \mathrm{M}$ & PCQE & $\begin{array}{l}\text { D1 } \\
\text { D5 } \\
\text { D7 } \\
\text { D8 }\end{array}$ & $\begin{array}{c}\text { T3.3 } \\
\text { T3.9 } \\
\text { T6.1 } \\
\text { T6.3 } \\
\text { T14.1 } \\
\text { T3.3 } \\
\text { T3.9 } \\
\end{array}$ & G1-10 \\
\hline \multirow{4}{*}{$\begin{array}{l}\text { Water Turbidity } \\
\text { Suspended } \\
\text { Particulate } \\
\text { Matter }\end{array}$} & & SRS & GOCI & $\begin{array}{l}\text { GOCI, the world's first geostationary ocean color } \\
\text { observation satellite, for the monitoring of } \\
\text { temporal variability in coastal water turbidity }\end{array}$ & [226] & $\mathrm{C} / \mathrm{M}$ & PCQE & D7 & $\begin{array}{c}\text { T6.3 } \\
\text { T14.1 }\end{array}$ & G9 \\
\hline & & SRS & GOCI & $\begin{array}{l}\text { Using GOCI data to map the diurnal dynamics of } \\
\text { suspended particulate matter in coastal waters }\end{array}$ & [227] & $\mathrm{C} / \mathrm{M}$ & PCQE & D8 & $\begin{array}{c}\mathrm{T} 6.3 \\
\mathrm{~T} 14.1\end{array}$ & G9 \\
\hline & General & $\begin{array}{l}\text { SRS } \\
\text { ARS } \\
\text { UAV } \\
\text { USV }\end{array}$ & - & $\begin{array}{l}\text { A Review of RS approaches for monitoring blue } \\
\text { carbon ecosystems: mangroves, seagrasses and } \\
\text { salt marshes }\end{array}$ & [228] & $\mathrm{C} / \mathrm{M}$ & \multirow{7}{*}{$\mathrm{BQE}$} & \multirow{7}{*}{ D1 } & & \multirow{7}{*}{$\begin{array}{c}\text { G1-5 } \\
\text { G7-8, G10 }\end{array}$} \\
\hline & General & UUV & - & $\begin{array}{l}\text { Monitoring marine habitats with } \\
\text { photogrammetry: a cost-effective, accurate, } \\
\text { precise and high-resolution reconstruction } \\
\text { method }\end{array}$ & [73] & $\mathrm{M}$ & & & & \\
\hline \multirow{7}{*}{$\begin{array}{l}\text { Marine Habitat } \\
\text { (Flora) }\end{array}$} & Wetlands & $\begin{array}{l}\text { SRS } \\
\text { ARS }\end{array}$ & - & A Review of wetland RS & [26] & C & & & $\begin{array}{l}\mathrm{T} 14.2 \\
\mathrm{~T} 15.1\end{array}$ & \\
\hline & Mangrove & $\begin{array}{l}\text { SRS } \\
\text { ARS } \\
\text { UAV } \\
\end{array}$ & - & A review of RS for mangrove forests: 1956-2018 & [229] & C & & & $\begin{array}{l}\mathrm{T} 15.5 \\
\mathrm{~T} 15.7 \\
\mathrm{~T} 12.2\end{array}$ & \\
\hline & Seagrass & $\begin{array}{c}\text { SRS/ARS } \\
\text { UAV/USV } \\
\text { UUV/SS }\end{array}$ & - & $\begin{array}{l}\text { Mapping, monitoring and modeling seagrass } \\
\text { using RS techniques }\end{array}$ & [230] & $\mathrm{C} / \mathrm{M}$ & & & & \\
\hline & Coral reefs & $\begin{array}{l}\text { SRS } \\
\text { ARS }\end{array}$ & - & $\begin{array}{c}\text { RS of coral reefs for monitoring and management: } \\
\text { a review }\end{array}$ & [231] & $\mathrm{C} / \mathrm{M}$ & & & & \\
\hline & $\begin{array}{c}\text { Vegetation } \\
\text { changes }\end{array}$ & SRS & Landsat & $\begin{array}{c}\text { Checking vegetation changes with SRS: The case } \\
\text { of the Trieste province (Italy) }\end{array}$ & [232] & $\mathrm{C}$ & & & & \\
\hline & General & $\begin{array}{l}\text { UAV } \\
\text { USV } \\
\text { UUV }\end{array}$ & - & $\begin{array}{l}\text { A review of unmanned vehicles for the detection } \\
\text { and monitoring of marine fauna }\end{array}$ & [70] & M & \multirow{4}{*}{$\mathrm{BQE}$} & \multirow{4}{*}{$\begin{array}{l}\text { D1 } \\
\text { D4 }\end{array}$} & \multirow{4}{*}{$\begin{array}{l}\mathrm{T} 14.4 \\
\mathrm{~T} 15.5 \\
\mathrm{~T} 15.7 \\
\mathrm{~T} 12.2\end{array}$} & \multirow{4}{*}{$\begin{array}{c}\text { G1-5 } \\
\text { G7-8, G10 }\end{array}$} \\
\hline & $\begin{array}{l}\text { Sea birds } \\
\text { and } \\
\text { Mammals }\end{array}$ & ARS & - & $\begin{array}{l}\text { Monitoring seabirds and marine mammals by } \\
\text { georeferenced aerial photography using ARS }\end{array}$ & [233] & M & & & & \\
\hline \multirow{2}{*}{$\begin{array}{l}\text { Marine Habitat } \\
\text { (Fauna) }\end{array}$} & Turtles & UUV with SRS & - & $\begin{array}{l}\text { Seasonal movements of immature Kemp's ridley } \\
\text { sea turtles (Lepidochelys kempii) using UUV }\end{array}$ & {$[234]$} & $\mathrm{M}$ & & & & \\
\hline & Sharks & SRS & - & $\begin{array}{c}\text { SRS in shark and ray ecology, conservation and } \\
\text { management }\end{array}$ & {$[235]$} & M & & & & \\
\hline
\end{tabular}


Table 3. Cont.

\begin{tabular}{|c|c|c|c|c|c|c|c|c|c|c|}
\hline State Changes & $\begin{array}{l}\text { Sub-State } \\
\text { Changes }\end{array}$ & $\begin{array}{l}\text { RS technology } \\
\text { SRS, ARS, UAV, } \\
\text { USV, UUV, SS }\end{array}$ & $\begin{array}{l}\text { If SRS Data } \\
\text { Satellite }\end{array}$ & Description/Application & Reference & $\begin{array}{l}\text { Environment } \\
\text { Coastal/Marine }\end{array}$ & $\begin{array}{c}\text { WFD } \\
\text { Indicators }\end{array}$ & $\begin{array}{c}\text { MSFD } \\
\text { Descriptors }\end{array}$ & $\begin{array}{c}\text { UN } \\
\text { SDG } \\
\text { Targets }\end{array}$ & $\begin{array}{l}\text { OHI } \\
\text { Goals }\end{array}$ \\
\hline $\begin{array}{c}\text { Benthic } \\
\text { Environment }\end{array}$ & & UUV & - & $\begin{array}{l}\text { Predicting the distribution of deep-sea vulnerable } \\
\text { marine ecosystems using high-resolution data }\end{array}$ & [236] & $\mathrm{M}$ & BQE & $\begin{array}{l}\text { D1 } \\
\text { D6 }\end{array}$ & $\begin{array}{l}\text { T14.4 } \\
\text { T15.5 }\end{array}$ & $\begin{array}{c}\text { G1-5 } \\
\text { G7-8, G10 }\end{array}$ \\
\hline Physical & $\begin{array}{l}\text { Sea surface } \\
\text { temperature }\end{array}$ & SRS & - & Half a century of SRS of sea-surface temperature & [237] & $\mathrm{C} / \mathrm{M}$ & PCQE & & & $\begin{array}{c}\text { G2-5 } \\
\text { G7-8, G10 }\end{array}$ \\
\hline Changes & $\begin{array}{l}\text { High wave } \\
\text { exposure }\end{array}$ & SRS & (Radar) & $\begin{array}{c}\text { Significant wave height measured by coherent } \\
\text { x-band radar SRS }\end{array}$ & [238] & $\mathrm{M}$ & HQE & D7 & $\begin{array}{l}\text { T14.1 } \\
\text { T14.4 }\end{array}$ & \\
\hline $\begin{array}{c}\text { Coastal } \\
\text { Landslides }\end{array}$ & & $\begin{array}{l}\text { SRS } \\
\text { UAV }\end{array}$ & ENVISAT & $\begin{array}{l}\text { The combined use of PSInSAR and UAV } \\
\text { photogrammetry techniques for the analysis of } \\
\text { the kinematics of a coastal landslide affecting an } \\
\text { urban area (SE Spain) }\end{array}$ & [239] & $\mathrm{C}$ & & & $\begin{array}{l}\text { T15.3 } \\
\text { T11.1 } \\
\text { T11.5 }\end{array}$ & $\begin{array}{l}\text { G5 } \\
\text { (Only if they } \\
\text { are related } \\
\text { to Sea level } \\
\text { rise) }\end{array}$ \\
\hline $\begin{array}{c}\text { Land } \\
\text { Subsidence }\end{array}$ & & SRS & $\begin{array}{l}\text { (Mainly) } \\
\text { Sentinel-1 }\end{array}$ & $\begin{array}{l}\text { SRS for monitoring land subsidence of coastal } \\
\text { cities in Africa }\end{array}$ & [240] & C & & D7 & $\begin{array}{l}\text { T15.3 } \\
\text { T11.1 } \\
\text { T11.5 }\end{array}$ & \\
\hline $\begin{array}{l}\text { Shoreline } \\
\text { evolution }\end{array}$ & & SRS & $\begin{array}{l}\text { Landsat } \\
\text { Gaofen-1 } \\
\text { (WFV) }\end{array}$ & $\begin{array}{l}\text { Shoreline evolution in an embayed beach adjacent } \\
\text { to tidal inlet: Using SRS }\end{array}$ & [241] & C & & D7 & $\begin{array}{l}\text { T13.1 } \\
\text { T11.1 } \\
\text { T11.5 }\end{array}$ & G5 \\
\hline $\begin{array}{l}\text { Turbidity } \\
\text { Plumes }\end{array}$ & & SRS & $\begin{array}{l}\text { Landsat } \\
\text { MODIS }\end{array}$ & $\begin{array}{l}\text { Detection of turbidity plumes and artificial } \\
\text { islands using RS data }\end{array}$ & [242] & $\mathrm{C} / \mathrm{M}$ & PCQE & D7 & T6.1 & G9 \\
\hline $\begin{array}{l}\text { Harmful Algal } \\
\text { Bloom }\end{array}$ & General & SRS & $\begin{array}{l}\text { CZCS, } \\
\text { SeaWiFS, } \\
\text { MODIS } \\
\text { MERIS }\end{array}$ & $\begin{array}{l}\text { A review of ocean color RS methods and } \\
\text { statistical techniques for the detection, mapping, } \\
\text { and analysis of phytoplankton blooms in coastal } \\
\text { and open oceans }\end{array}$ & [90] & $\mathrm{C} / \mathrm{M}$ & $B Q E$ & D5 & $\begin{array}{c}\text { T3.9 } \\
\text { T6.1 } \\
\text { T6.3 } \\
\text { T14.1 } \\
\text { T14.3 }\end{array}$ & $\begin{array}{l}\text { G1, G2, G3, } \\
\text { G4, G5, G6, } \\
\text { G7, G8, G9, } \\
\text { G10 }\end{array}$ \\
\hline pH Changes & General & SRS & - & $\begin{array}{l}\text { RS of surface ocean PH exploiting sea surface } \\
\text { salinity satellite observations }\end{array}$ & [243] & $\mathrm{M}$ & PCQE & & T6.1 & \\
\hline
\end{tabular}




\subsubsection{Coastal and Marine Habitats}

There are different types of coastal and marine habitats, such as wetlands, coastal vegetation, salt marshes, mangroves, seagrasses, coral reefs, and kelp beds, that provide a range of valuable goods and services to the environment and humans. The mapping of coastal and marine habitats is a preliminary step for studies of ecosystems. Pham et al., 2019 [227] presented a comprehensive review of RS data used for mapping and monitoring blue carbon ecosystems (mangroves, seagrasses, and salt marshes), including high spatial resolution and medium/low spatial resolution with different sensors from SRS, ARS, UAV, and USV. The review covers studies undertaken from 2010 to 2018. Furthermore, [73] developed a cost-effective UUV, using a photogrammetry approach that can produce accurate and precise high-resolution models to monitor marine habitats on a small scale (e.g., biogenic reefs and seagrass meadows).

- Wetlands

Coastal wetlands play an important role in protecting communities from climate change impacts, as they moderate the climate and at the same time, are vulnerable ecosystems [36,247]. RS applications provide knowledge to understand the functioning process of these ecosystems. Guo et al., 2017 [26] provided an overview of the application of SRS and ARS data to wetland research by reviewing seven types of sensors. These include aerial photos with coarse-resolution, medium-resolution, high-resolution, hyperspectral imagery, radar, and LiDAR data to track the changes in wetland ecosystems.

\section{- Mangrove Change}

Mangroves are highly productive ecosystems on tropical coasts. Their changing state can impact the entire surrounding ecosystems. RS applications for mangroves include distribution, biophysical parameter identification, and characterization of their state. Wang et al., 2019 [228] highlighted the major RS development for mangroves by reviewing historical research from 1956 to 2018. This includes SRS, ARS, and UAV uses for understanding and analysing these ecosystems. Furthermore, different aspects were reviewed, including extent (area) mapping, leaf area index estimation, species classification, height estimation, carbon stock estimation, health assessment, carbon flux characterization, ecohydrology, and climate impact on mangroves.

\section{- $\quad$ Seagrass}

Seagrasses are foundation species for physio-chemical and biological processes in coastal and marine ecosystems [248]. They also provide habitat for other organisms, such as juvenile fish and invertebrates. Numerous studies have documented the advantages of RS technologies for seagrass research: SRS [249,250], ARS [251], UAV [252] to USV, and SS [253]. To assess the state change of seagrasses, [229] presented an overview of the RS platforms that can be used to assess state changes, measure biophysical properties, map, monitor, and model the seagrasses ecosystem, as well as specifying the environmental conditions that do not allow the RS and their approaches to work.

\section{- Coral Reefs}

Coral reef communities are facing state changes and are even in decline worldwide due to natural and anthropogenic pressures from different activities at the local, regional, and global scales [254,255]. To assess and measure the effects of such pressures in complex coastal and marine ecosystems, RS are becoming keystone technologies to tackle this crisis and that can be deployed as well to quantify their distribution and their changes [256]. Hedley et al., 2016 [230] presented a full review of RS technologies that can be applied to monitor and manage changes in coral reefs ecosystems, including SRS and ARS. 
- Macroalgae

High-Resolution SRS Observations have been used as well to detect Sargassum blooms [257]. In general, these macroalgae can grow so large that they blanket coastlines or can cover large areas of the sea, such as the case of green tides that occurred for eleven consecutive years in the Yellow Sea [258].

\section{- Vegetation Change}

Coastal vegetation is effective for protecting coastal cities from sea storms and, also, from erosion on the watershed and their rivers. Their changes might impact the ecosystems, such as a change in sedimentation flux, water flux, and biodiversity changes. Favretto, 2018 [231] applied a change detection analysis to the thematic map time series by SRS from Landsat to assess the forest vegetation changes in the Trieste province of Italy through the use of an Enhanced Vegetation Index (EVI) as a suitable index for their physical characteristics.

\subsubsection{Marine Fauna}

Marine fauna provides a variety of ecosystem services for nature and humans, such as food (provisioning service) and cetacean watching (cultural service). However, human activities and resulting pressures degrade the health and sustainability of marine fauna. RS technologies have been used for tracking marine fauna to monitor and assess changes in their status. Satellite telemetry has been used for marine animal surveys to follow a target and track movement.

Recently, UAVs, USVs, and UUVs have provided many new advantages to detect and monitor marine fauna and their state change. There have been improvements in mission safety and repeatability, longer survey durations, and reducing costs. Verfuss et al., 2019 [70] highlighted suitable systems for three monitoring systems of marine fauna, including population, mitigation, and focal animal monitoring.

- Sea Birds and Marine Mammals

Sea birds and marine mammals include important "top predator" species of the marine ecosystem. RS technologies have been increasingly used for research on seabirds and mammals in recent years. Kemper et al., 2016 [232] used the ARS approach to detect and identify marine mammal species or a species group using a twin-camera system that generates high-quality images. This approach can be applied to complement land-based species counts.

- $\quad$ Turtles

Satellite telemetry has been used to track the movement of turtles and changes. Coleman et al., 2017 [233] used a UUV attached to the back of sea turtles (called Platform Terminal Transmitter PPT) that is tracked with earth-orbiting satellite to follow the movement of turtles. The collected data showed changes that happened in the Mississippi-Gulf region.

\section{- Sharks}

Sharks are also important apex predator species of the marine ecosystem. Their populations have been declining during the last five decades, with resulting state change in many marine ecosystems [259]. SRS has been used in many research studies to follow the activities and pressures, causing the decline of sharks. Williamson et al., 2019 [234] presented a global map that shows the regions where SRS has been deployed for shark ecology and conservation, showing a common tagging technology.

\subsubsection{Benthic Environment}

Activities and pressures to the marine environment affect the spatial distribution of benthic species in both shallow waters and the deep sea, which contributes to the state change of these benthic 
ecosystems. Rengstorf et al., 2014 [235] provided an overview of methodologies used to predict the distribution of deep-sea benthic species. The Irish remotely-operated vehicle (ROV) Holland I and a UUV were deployed to assess the benthos by using high-resolution imagery. This enabled the assessment of changes and illustrated the emerging issues.

\subsubsection{Physical Parameter Changes}

The physical parameters of seawater can be measured directly and indirectly. Direct in situ measurements can be expensive to carry out in the field. RS applications are often the most cost-effective and fit for purpose options to assess these parameters and changes that affect the environmental state of the coastal and marine ecosystems. Some of the important physical parameters are sea surface temperature (SST), sea currents, and waves.

- $\quad$ Sea Surface Temperature (SST)

SST is the most important physical parameter to be measured to monitor the state change and the health of the coastal and marine environments. Several anthropogenic activities and pressures can affect SST, and most of the marine ecosystems can be affected. Examples of this are widespread coral bleaching events. SRS data provides a comprehensive view of the coastal and marine ecosystems and allows a synoptic measurement of SST, which has been used in research worldwide [260-263]. Minnett et al., 2019 [236] provided a half-century of the historical development of SRS sensors to measure SST. The challenges of data volumes, distribution, analysis, and communication are included.

\section{- High Wave Exposure}

The measurement of wave height and storm surge is essential for coastal protection, shipping, and offshore operations. Anthropogenic activities and pressures can increase the vulnerability to natural hazards, for example, by urbanizing low-lying coasts. Low-lying coastal urban areas and atolls are key societal hotspots of coastal vulnerability and changes in wave exposure [264]. Radar images have been the most significant sensors used to assess changes in wave and to estimate wave height $[237,265,266]$. SRS contributes to increasing operational awareness and human safety and many marine applications.

\subsubsection{Coastal Landslide}

Landslides have impacted coastal structures, cliffs, and hillsides in many regions around the world. These are associated with an increase of severe weather events associated with climate change [267]. They are also related to urbanization activities and pressures [268]. The most extreme coastal landslide example known in the Mediterranean coast (Cármenes del Mar resort, Granada, Spain) was assessed by deploying SRS using ENVISAT SAR images and a UAV using the photogrammetry approach, and both applications allowed quantifying the changes of building displacements and the structural changes as well [238].

\subsubsection{Land Subsidence}

Growing urbanization in major coastal cities has led to various activities and pressures, such as overexploiting groundwater, reclaiming lands, and built-up areas [269]. These result in a state change on the coastal environment causing surface deformation and land subsidence, especially in river-mouth systems [270]. RS can be deployed to identify the areas most vulnerable to land subsidence. Cian et al., 2019 [239] used SAR data from SRS Sentinel-1 images and applied Persistent Scatterer Interferometry (PSI) technique as a powerful tool able to monitor displacements of the Earth's surface over time [271]. The research integrated the Sentinel Application Platform (SNAP) and the Stanford Method for Persistent Scatterers (StaMPS), which showed the potential to monitor land subsidence and coastal resilience assessment in many African coastal cities. 


\subsubsection{Shoreline Changes}

Coastal erosion pressures usually lead to beach and shoreline changes due to different anthropogenic activities. Historical RS data can document the evolution of coastal shorelines and their changes. Zhang et al., 2019 [240] used SRS from Landsat and Gaofen-1 (WFV) satellites to extract shoreline data and their evolution for 20 years, to detect the state changes of Wenchang City beach, in South China.

\subsubsection{Turbidity Plumes}

Turbidity plumes are mostly produced during dredging and drilling activities and cause a state change in the marine environment. They can be detected through RS images. For instance, building an artificial island in the South China sea has led to turbidity plumes that were detected through SRS using Landsat and MODIS data [241]. A turbidity index was developed as a simple subtraction algorithm difference between two Rayleigh-corrected reflectances at 469 and $645 \mathrm{~nm}$ [272], which allowed for easy detection of turbidity plumes [241].

\subsubsection{Harmful Algal Blooms}

Algal blooms are considered a major indicator of marine ecosystem health, which shows the state change of the environment. Hence, a variety of operational RS sensors have been developed to assess the HAB during the last four decades [273-275]. Progress and limitations of the developed algorithms used through multispectral ocean colour SRS sensors, such as CZCS, SeaWiFS, MODIS, and MERIS, have been discussed and reviewed by [90] in order to understand the triggering factors behind algal blooms and to analyse their spatio-temporal patterns in coastal and open-sea ecosystems.

\subsubsection{3. $\mathrm{pH}$ Changes}

Ocean $\mathrm{pH}$ is an important environmental variable to assess coastal and marine health ecosystems. Ocean acidification is a decrease in $\mathrm{pH}$ that causes a major state change on marine organisms and environments. The surface ocean $\mathrm{pH}$ has been estimated through $\mathrm{RS}$ application in many ocean regions. Sabia et al., 2015 [242] presented the best appropriate approach to estimate surface ocean $\mathrm{pH}$ through the combination of different existing SRS datasets to unify the fragmented RS study and to generate a novel value-added SRS product.

\subsection{RS and Impact (on Welfare)}

Changes in the environment that have consequences for societal welfare (goods and benefits) are considered as an impact (on human welfare) [7]. At present, only the impacts presenting risk to public health (e.g., gas emission) and risk to public life and infrastructure (e.g., storm surge) can be assessed using RS technologies. Other economic and social impacts (e.g., loss of jobs, loss of revenue) are assessed differently. Table 4 summarizes the recent advanced application of RS in relation to the main impact (on welfare).

Table 4. The remote sensing applications that are being developed for each impact (on welfare).

\begin{tabular}{|c|c|c|c|c|c|}
\hline $\begin{array}{l}\text { Impact (on } \\
\text { Welfare) }\end{array}$ & $\begin{array}{l}\text { Sub-Impact } \\
\text { (on Welfare) }\end{array}$ & $\begin{array}{c}\text { RS Technology } \\
\text { SRS, ARS, UAV, USV, UUV, SS }\end{array}$ & $\begin{array}{l}\text { If SRS Data } \\
\text { Satellite }\end{array}$ & Description/Application & Reference \\
\hline $\begin{array}{c}\text { Public Health } \\
\text { Risk }\end{array}$ & Gas Emission & UAV & - & $\begin{array}{l}\text { Towards the development of a } \\
\text { low-cost airborne sensing } \\
\text { system to monitor dust } \\
\text { particles after blasting at } \\
\text { open-pit mine sites }\end{array}$ & [276] \\
\hline $\begin{array}{l}\text { Risk to Public } \\
\text { Life and } \\
\text { Infrastructures }\end{array}$ & Storm surge & SRS & MODIS & $\begin{array}{l}\text { Global mapping of storm } \\
\text { surges and the assessment of } \\
\text { coastal vulnerability }\end{array}$ & [277] \\
\hline
\end{tabular}




\subsubsection{Public Health Risk}

Public health risks impact human health through disease or infectious environmental conditions. Industrial waste gas emission represents a better case for impacting human health and health care expenditure [278]. As air quality monitoring methods use a limited number of fixed sampling, RS technologies that cover a larger area can help to assess the gas emission and dispersion that can affect human health. Neumann et al., 2013 [279] developed a bio-inspired and particle filter-based algorithm to localize a gas emission and its source using a micro-drone as a UAV. A list of RS technologies that were used for monitoring gases is presented by [276].

\subsubsection{Risk to Public Life and Infrastructure}

Storm surges pose some of the most devastating hazards to coastal regions that represent a risk to human life and/or an impact on its welfare, as they are both deadly and costly $[280,281]$. RS applications are effective for impact assessment and future prediction, while ground surveys to assess a post-surge impact are expensive, laborious, and lack a spatial dimension. Brakenridge et al., 2013 [277] surveyed an SRS application for three catastrophic storm surges worldwide and presented a global mapping approach to assess coastal impact and vulnerability.

\subsection{RS as a Response (as Measure)}

Coastal and marine responses are measures to be taken to face changes resulting from drivers, activities, and pressures. Besides the strengths that RS technologies have had on the first DAPSI(W)R(M) component, "D-A-P-S-I $(\mathrm{W})$ ", the application of these technologies can be a major response (as measure) in emerging and developing economies countries by building a collaborative unit and practical framework that will integrate all sectors that can use RS in order to assess and monitor drivers, activities, pressures, and state change on their coastal and marine environment.

The measures should follow the 10-tenets approach for adaptive management and sustainability, developed by [282].

Ecological RS applications with the different sensors have proven to be useful, such as the monitoring of blue carbon ecosystems [227,283], habitat [284], and valuation of ecosystem services $[285,286]$. For instance, coral reef restoration as a measure could be addressed by using RS technologies as they provide information on various abiotic conditions and other site characteristics [287].

Another essential response (as a measure) is to use low cost SS to obtain and communicate significant parameters to monitor the coastal and marine environment. Lay Ekuakille et al., 2019 [288] presented the advances in SS that could help to monitor water quality.

To manage natural resources and protect the coastal and marine ecosystems in conflict zones, RS can be used to access politically sensitive areas [289].

Civil security and public safety due to natural hazard (e.g., floods and hurricanes) and/or anthropogenic disaster (e.g., industrial waste gas emission and broken dams) that may occur in coastal and marine areas could be assessed using RS technologies. For instance, UAVs have shown great potential in their application as a response to the disaster [290].

\section{Discussion}

RS technologies present an opportunity to assess and analyse important elements of the $\operatorname{DAPSI}(\mathrm{W}) \mathrm{R}(\mathrm{M})$ framework. Despite their strengths, the advances in RS sensors still have limitations and offer challenges to enable a holistic coastal and marine management application. Therefore, there are still large improvements to be made to achieve environmental integration for assessment and monitoring. Challenges facing current sensors for future uses, opportunities, and recommendations to move toward integrated management, as well as recommendations to overcome the challenges, are presented in the following sections (Sections 4.1 and 4.2). 


\subsection{Limitations of Current Technologies and Challenges}

There are some limitations to existing RS technologies and challenges for their application that should be addressed to implement integrated coastal and marine environmental management. Current RS technology is still not developed enough to monitor complicated ecosystems, presenting deficiencies in many aspects, such as sensors, used technologies, data collection, storage, uncertainties, extrapolation, affordability, accessibility, dissemination, communication, and political issues.

\subsubsection{Technology-Based Challenge}

The challenges here consider the RS technologies reviewed under this research: SRS, ARS, UAV, USV, UUV, and SS.

SRS Challenges: Despite the wide-ranging observation of coastal and marine ecosystems over a large spatio-temporal scale through SRS, satellite data still offer challenges. Their resolutions are generally coarser compared to other sensors related to the assessment of specific target activities (e.g., livestock and aquaculture), pressures (e.g., underwater noise and presence of marine litter), and state changes (e.g., marine habitat). Most of the SRS-based research has so far been focused on a few aspects related to coastal and marine environments. Past datasets derived from previous SRS missions are limited by the coarse resolution to perform time series analysis and predict future state changes and impacts. Some SRS sensors present significant uncertainties for the detection of variables: for instance, due to noise, oil spill pressure detection is limited when using spaceborne polarimetric SARs [213].

ARS challenges: ARS images still need improvement for flight pathways with georeferenced lines [291]. The resulting images need to be processed in standardized ways to match with other sensors. ARS missions remain expensive compared to other sensors.

Due to wide flight lines along coastal and marine environments, the collected data could be ambiguous for some specific targets.

$U A V$ challenges: UAV missions are often carried out by private research teams, private companies, individual institutions, or individuals. The data are not free and can be costly as well. Despite technological advances with rechargeable batteries, a limited flight duration, mostly less than an hour (mostly small UAV), hampers the ability to cover larger areas and time of the mission; thus, reduced autonomy is challenging [292]. While aircraft UAV is capable of reaching altitudes above $12 \mathrm{~km} \mathrm{[293],}$ small UAVs still have limited altitude. Limitations to available weight capacity reduce the availability of sensors that can assess specific coastal and marine components, especially for a small UAV [294]. Operational safety for UAV missions remains challenging. Attaining extended distances at sea from a coastal mission still needs improvement. A limited flying attitude may disturb wildlife [295]. Finally, coordinating several UAVs during surveillance and pursuit also remains challenging [296].

USV challenges: Automated and reliable guidance and navigation for USV remains challenging; also, USV sensing faces limitations from water reflections and visual noises. Hydrodynamic forces and moments are still not fully understood to perform a stable USV mission [71]. Surveys under extreme weather conditions to assess long-term impacts also remain challenging [297].

UUV challenges: Many factors make the underwater environment challenging, such as the lack of GPS information on positioning the UUV and its sensors, impact of light refraction on reducing field view, as well as underwater clarity and turbidity that could affect the image quality [73,298,299]. UUV's potential risks for disturbing animals is also a challenging task. Avoiding collision between multiple UUVs surveys within their path planning in the complicated marine environments is challenging [300].

SS limitations: Limited coverage and limited expansion are the challenging gaps that exist on the SS application to derive in situ observations. The SS network's communication between different devices remains challenging. 


\subsubsection{Uncertainties}

RS-derived images are subject to large uncertainties due to the ecosystem complexity of the coastal and marine environments. For instance, coastal shallow water has a high reflectance, which contributes to ambiguity for data acquisition [301]. Furthermore, the accumulation of uncertainties at various levels of satellite data processing could generate inaccurate results and interpretation. Therefore, associating uncertainties to a specific variable when assessing coastal and marine parameters is a challenging task. In general, the uncertainty aspect should be revisited in greater detail for each applied method and thus for each parameter.

\subsubsection{Accessibility and Affordability}

Over the last decades, there have been many applications of RS technologies to assess coastal and marine ecosystems. Many satellites have been launched, and many sensors have been developed due to environmental concerns. However, most of the advances have been centered on the use of data, including acquisition, processing, storing, manipulating, and integrating. There have been significant improvements in the understanding and analysis of environmental issues at the local, regional, and global scale. Nevertheless, accessibility and affordability of RS data is still a challenging issue, especially in countries with limited economic resources.

What are the most pressing challenges? Growing volumes of new high-resolution images are creating challenges for data access. It is costly to build infrastructure, tools, and platforms to access data, and many products are still costly. Capacity building and training of human resources are also costly. UAV, USV, ARS, and UAV data are often still held in private use by research teams, institutions, or private industries, which make access to their data complicated and/or costly.

\subsubsection{Data Storage, Integration, Communication, and Dissemination}

RS data collection is improving, but what are the remaining challenges? There are challenges in regulating effective data storage frameworks and creating standardized protocols for archiving data with emphasis on the marine application. Integrating different data from different RS sources is challenging due to a lack of cooperation between different data holders and a lack of homogeneous protocols. Communication between data holders and data users is also challenging. The coastal and marine research community faces challenges in the dissemination of data and uptake of results to develop integrated coastal marine management.

\subsubsection{Policies and Legal Issues}

At global scales, countries performing SRS missions that can legally collect environmental data could make this data available to other countries. This is a political and ethical issue that has yet to be addressed. RS technologies should be considered as a tool to support integrated coastal and marine management frameworks that are aiming to achieve a healthy environment.

As marine areas are shared between countries, international collaboration is essential to ensure the use of collaborative information from RS technologies. However, an open exchange of RS data is often still challenging. Political issues still create barriers to the free dissemination of data, even for environmental purposes. Regulations regarding the use of UAV, USV, and SS for scientific purposes are still challenging for the scientific community in countries where complicated permissions are required.

\subsubsection{Fragmented Expertise and Institutions:}

There is growing knowledge and appreciation of RS applications. Expertise on the use of these technologies for coastal and marine management is still fragmented or siloed. Expertise regarding coastal ecosystems (e.g., lagoons, estuary, and deltas), marine ecosystems (e.g., operational oceanography, offshore energy, and marine habitat) and remote sensing technologies are often separate; for instance, coastal or marine experts might not have an understanding of RS applications and 
vice versa. Furthermore, RS users might not be knowledgeable about processing RS data. Similarly, institutional specialization can constrain coordination and data transfer, which represents a challenge for knowledge sharing and integrated assessment.

\subsection{Opportunities for Improving the Integrated Coastal and Marine Environmental Management Framework}

Despite the challenges, there are substantial opportunities to use RS for a further understanding of water and coastal ecosystems and to improve their management, especially using social-environmental approaches, such as the DAPSI(W)R(M) framework.

SRS data presents an opportunity to analyse important environmental factors through new satellite generation, such as the sentinel missions from the EU, which are presenting free accessible data through their different platforms and providing already processed data. High resolution data are presenting an unprecedented knowledge about the coastal and marine environment. Moreover, rather than using the inertial navigation system, SAR data as an SRS application could support UAV navigation [302].

UAV is revolutionizing data acquisition for specific targets related to activities, pressures, and state change assessment. Increasing the levels of battery autonomy, reaching higher altitudes, networking capability, and lowering costs are advancing research on the coastal environment. Coordination between a network of UAVs could help cover larger areas [303].

SS sensors and their automation are increasing in efficiency and efficacy of data precision, through the technology's development. Sampling surveys for oceans are expensive and time-consuming. Therefore, USV and UUV are bringing insights and knowledge about deep-sea life, habitats, sediment, and water quality. The integration of datasets from different sensors has provided a growing ecological understanding of coastal and marine species for conservation purposes.

RS technologies are facilitating the policing of illegal activities, such as illegal fisheries, illegal sand mining, overfishing, vessel waste discharge, and oil spills that can negatively impact the ecosystem services provided by coastal and marine environments.

Application of algorithms to RS data are useful to develop an understanding of the environment. For instance, artificial neural network algorithms have been applied for statistical regression, image classification, image segmentation, and many other aspects of RS processing [304]. Furthermore, deep learning algorithms for RS imagery analysis are rising in popularity, which can perform image fusion and registration, object detection, land use and land cover classification, segmentation, object detection, and even accuracy assessment [305], which will provide significant progress to the analysis of RS imagery of coasts and marine ecosystems [306].

Approaches to augmented reality will provide a new type of knowledge. RS data can be used to virtually reconstruct coastal and marine environments. Stakeholders and the larger public will be able to view, analyse, and interact with these environments [307].

The Internet of Things (IoT) systems are playing a role in advancing the development of different coastal and marine environments by accessing, securing, managing, and controlling data infrastructures [308,309]. This allows the monitoring of environmental conditions by communicating data from different networks into a single infrastructure. Data privacy protection, big data transmission, and data integration and processing on a large scale through IoT present a big opportunity to understand the environment.

Model-based RS data and free access to RS images through collaborative initiatives, such as the Copernicus Data and Information Access Services, at a regional level (EU), have facilitated information access to processed data. This has boosted users' innovation and created new research perspectives [21,310].

The incorporation of RS products into integrated coastal and marine management frameworks, such as DAPSI $(\mathrm{W}) \mathrm{R}(\mathrm{M})$, is key to map information in a structured way. Such information can support the analysis of these complex ecosystems and presents a greater opportunity to achieve sustainable development. 


\section{Conclusions}

RS technologies have become an essential tool to support the coastal and marine integrated management framework, such as the DAPSI $(\mathrm{W}) \mathrm{R}(\mathrm{M})$ application. The use of RS has expanded rapidly, and data available from different sensors has increased their utility. SRS, ARS, UAV, USV, UUV, and SS advances provided accurate measurement and mapping of numerous parameters associated with the $\mathrm{DAPSI}(\mathrm{W}) \mathrm{R}(\mathrm{M})$ components, from detecting to quantifying and monitoring activities, pressures, state changes, and impact (on welfare).

This article focuses on the relevant RS research related to coastal and marine ecosystems through an integrated coastal and marine environmental management framework and shows the role of emerging RS technologies to support this integration and to support the implementation of environmental directives policies, such as WFD, MSFD, SDG, and OHI.

RS presents many opportunities to improve our understanding of coastal and marine ecosystems. Nevertheless, there are still challenges and significant shortcomings related to RS application. These include technological advances, affordability and access, legal issues, fragmented knowledge, data communication, and dissemination.

Harmonizing regional, national, international, and interdisciplinary efforts between RS, coast and marine experts, as well as other stakeholders are essential. This can generate advanced knowledge to achieve sustainable development of our coasts and marine ecosystems. Future studies should focus on the contribution of RS technologies to the use and best practices for the management of the coastal zone

Author Contributions: Conceptualization, B.E., A.N., J.D.I. and I.K.; data curation, B.E., J.D.I. and S.A.; formal analysis, B.E., A.N., J.D.I. and I.K.; funding acquisition, B.E. and M.S.; investigation, B.E.M. and S.A.; methodology, B.E.M., A.N. and J.D.I; project administration, B.E.; supervision, A.N. and I.K.; validation, A.N. and J.D.I.; visualization, B.E.; writing—original draft, B.E.; writing—review and editing, B.E., A.N., J.D.I., I.K., S.A. and M.S. All authors have read and agreed to the published version of the manuscript.

Funding: This work was funded and supported by the Murray Foundation supporting student-research, https://www.murrayfoundation.eu, Grant Agreement No. 25.26022020.

Acknowledgments: Badr El Mahrad would like to thank Stefano Salon for his valuable help, knowledge sharing, and support, and also, he would like to acknowledge the Murray Foundation, Centro de Investigacão Marinha e Ambiental, Scientific Association for Water Information System, Sustainable Blue Growth programme, BlueMed Initiative and Lagoons for Life Network. Alice Newton acknowledges SCOR, Future Earth Coasts, IMBeR, and Future Earth Ocean KAN. This article is dedicated to Professor Trevor Platt, an inspiring Marine Scientist.

Conflicts of Interest: The authors declare no conflict of interest.

\section{Nomenclature:}

- $\quad$ Earth observation techniques can be applied for the implementation of environmental directives, such as WFD and MSFD.

- Remote sensing (RS) can be a useful tool for integrated coastal and marine environmental management frameworks.

- $\quad$ An overview of RS uses for an expanded DPSIR framework is presented.

- Challenges, knowledge gaps, and opportunities of RS for DAPSI(W)R(M) are highlighted.

- Emerging earth observation (data acquisition) technologies can help improve environmental understanding for better resource management and attaining SDGs.

\section{References}

1. Small, C.; Nicholls, R.J. A global analysis of human settlement in coastal zones. J. Coast. Res. 2003, 19, 584-599.

2. Balk, D.; Montgomery, M.; McGranahan, G.; Kim, D.; Mara, V.; Todd, M.; Buettner, T.; Dorélien, A. Mapping urban settlements and the risks of climate change in Africa, Asia and South America. Popul. Dyn. Clim. Chang. 2009, 80, 103.

3. He, Q.; Bertness, M.D.; Bruno, J.F.; Li, B.; Chen, G.; Coverdale, T.C.; Altieri, A.H.; Bai, J.; Sun, T.; Pennings, S.C.; et al. Economic development and coastal ecosystem change in China. Sci. Rep. 2014, 4, 5995. [CrossRef]

4. El Mahrad, B.; Abalansa, S.; Newton, A.; Icely, J.D.; Snoussi, M.; Kacimi, I. Social-environmental analysis for the management of coastal lagoons in North Africa. Front. Environ. Sci. 2020, 8, 37. [CrossRef] 
5. World Resources Institute. Millennium Ecosystem Assessment Ecosystems and Human Well-Being: Biodiversity Synthesis; World Resources Institute: Washington, WA, USA, 2005.

6. Ostrom, E. A general framework for analyzing sustainability of social-ecological systems. Science 2009, 325, 419-422. [CrossRef]

7. Elliott, M.; Burdon, D.; Atkins, J.P.; Borja, A.; Cormier, R.; De Jonge, V.N.; Turner, R.K. “And DPSIR begat DAPSI(W)R(M)!"-A unifying framework for marine environmental management. Mar. Pollut. Bull. 2017, 118, 27-40. [CrossRef] [PubMed]

8. Kennedy, R.E.; Townsend, P.A.; Gross, J.E.; Cohen, W.B.; Bolstad, P.; Wang, Y.Q.; Adams, P. Remote sensing change detection tools for natural resource managers: Understanding concepts and tradeoffs in the design of landscape monitoring projects. Remote Sens. Environ. 2009, 113, 1382-1396. [CrossRef]

9. Ndzabandzaba, C. Data sharing for sustainable development in less developed and developing countries. Glob. Sustain. Dev. Rep. 2015. Available online: https://wedocs.unep.org/bitstream/handle/20.500.11822/ 9849/-Global_Sustainable_Development_Report_-_Advanced_Unedited_Version-2015GSDR_2015.pdf. pdf? sequence=3\&isAllowed $=y$ (accessed on 30 April 2020).

10. Directive, Strategic Environmental Assessment. European Commission Directive 2000/60/EC of the European parliament and of the council of 23 October 2000 establishing a framework for community action in the field of water policy. Off. J. Eur. Communities 2000, 22, 2000.

11. Directive, Strategy Framework. European Commission Directive 2008/56/EC of the European parliament and of the council of 17 June 2008 establishing a framework for community action in the field of marine environmental policy. Off. J. Eur. Union L 2008, 164, 19-40.

12. European Environment Agency. EEA Data Policy Report; København, K., Ed.; European Environment Agency: Copenhagen, Denmark, 2013.

13. United Nations. Transforming Our World: The 2030 Agenda for Sustainable Development; United Nations: San Francisco, CA, USA, 2015.

14. United Nations. The Sustainable Development Goals Report 2016; United Nations: San Francisco, CA, USA, 2016.

15. Halpern, B.S.; Longo, C.; Hardy, D.; McLeod, K.L.; Samhouri, J.F.; Katona, S.K.; Kleisner, K.; Lester, S.E.; O'Leary, J.; Ranelletti, M.; et al. An index to assess the health and benefits of the global ocean. Nature 2012, 488, 615-620. [CrossRef] [PubMed]

16. Strong, J.A.; Elliott, M. The value of remote sensing techniques in supporting effective extrapolation across multiple marine spatial scales. Mar. Pollut. Bull. 2017, 116, 405-419. [CrossRef] [PubMed]

17. Cristina, S.; Icely, J.; Goela, P.C.; DelValls, T.A.; Newton, A. Using remote sensing as a support to the implementation of the European Marine Strategy Framework Directive in SW Portugal. Cont. Shelf Res. 2015, 108, 169-177. [CrossRef]

18. Sanders, K.T.; Masri, S.F. The energy-water agriculture nexus: The past, present and future of holistic resource management via remote sensing technologies. J. Clean. Prod. 2016, 117, 73-88. [CrossRef]

19. Melesse, A.M.; Weng, Q.; Thenkabail, P.S.; Senay, G.B. Remote sensing sensors and applications in environmental resources mapping and modelling. Sensors 2007, 7, 3209-3241. [CrossRef] [PubMed]

20. Fingas, M. Remote sensing for marine management. World Seas Environ. Eval. 2019. [CrossRef]

21. Le Traon, P.Y.; Reppucci, A.; Fanjul, E.A.; Aouf, L.; Behrens, A.; Belmonte, M.; Bentamy, A.; Bertino, L.; Brando, V.E.; Kreiner, M.B.; et al. From observation to information and users: The copernicus marine service perspective. Front. Mar. Sci. 2019, 6, 234. [CrossRef]

22. Voulvoulis, N.; Burgman, M.A. The contrasting roles of science and technology in environmental challenges. Crit. Rev. Environ. Sci. Technol. 2019, 49, 1079-1106. [CrossRef]

23. Vihervaara, P.; Auvinen, A.-P.; Mononen, L.; Törmä, M.; Ahlroth, P.; Anttila, S.; Böttcher, K.; Forsius, M.; Heino, J.; Heliölä, J.; et al. How essential biodiversity variables and remote sensing can help national biodiversity monitoring. Glob. Ecol. Conserv. 2017, 10, 43-59. [CrossRef]

24. Murray, N.J.; Keith, D.A.; Bland, L.M.; Ferrari, R.; Lyons, M.B.; Lucas, R.; Pettorelli, N.; Nicholson, E. The role of satellite remote sensing in structured ecosystem risk assessments. Sci. Total Environ. 2018, 619, $249-257$. [CrossRef]

25. Unninayar, S.; Olsen, L.M. Monitoring, observations, and remote sensing - global dimensions. Ref. Modul. Earth Syst. Environ. Sci. 2015. [CrossRef]

26. Guo, M.; Li, J.; Sheng, C.; Xu, J.; Wu, L. A Review of wetland remote sensing. Sensors 2017, 17, 777. [CrossRef] [PubMed] 
27. Bean, T.P.; Greenwood, N.; Beckett, R.; Biermann, L.; Bignell, J.P.; Brant, J.L.; Copp, G.H.; Devlin, M.J.; Dye, S.; Feist, S.W.; et al. A Review of the tools used for marine monitoring in the UK: Combining historic and contemporary methods with modeling and socioeconomics to fulfill legislative needs and scientific ambitions. Front. Mar. Sci. 2017, 4, 263. [CrossRef]

28. Gari, S.R.; Newton, A.; Icely, J.D. A review of the application and evolution of the DPSIR framework with an emphasis on coastal social-ecological systems. Ocean Coast. Manag. 2015, 103, 63-77. [CrossRef]

29. OECD. Environmental Indicators- OECD Core Set; OECD: Paris, France, 1994; p. 37.

30. EEA. Europe's Environment: The Dobris Assessment; Report No 1/1995; European Environmental Agency: Copenhagen, Denmark, 1995; 8p.

31. Cormier, R.; Elliott, M. Smart marine goals, targets and management-Is SDG 14 operational or aspirational, is 'Life Below Water' sinking or swimming? Mar. Pollut. Bull. 2017, 123, 28-33. [CrossRef] [PubMed]

32. Lovecraft, A.L.; Meek, C.L. Arctic coastal systems: Evaluating the DAPSI(W)R(M) framework. Coasts Estuaries 2019. [CrossRef]

33. Burdon, D.; Barnard, S.; Boyes, S.J.; Elliott, M. Oil and gas infrastructure decommissioning in marine protected areas: System complexity, analysis and challenges. Mar. Pollut. Bull. 2018, 135, 739-758. [CrossRef]

34. Kaikkonen, L.; Venesjärvi, R.; Nygård, H.; Kuikka, S. Assessing the impacts of seabed mineral extraction in the deep sea and coastal marine environments: Current methods and recommendations for environmental risk assessment. Mar. Pollut. Bull. 2018, 135, 1183-1197. [CrossRef]

35. Dale, P.; Sporne, I.; Knight, J.; Sheaves, M.; Eslami-Andergoli, L.; Dwyer, P. A conceptual model to improve links between science, policy and practice in coastal management. Mar. Policy 2019, 103, 42-49. [CrossRef]

36. Newton, A.; Icely, J.; Cristina, S.; Perillo, G.; Turner, R.E.; Ahsan, D.; Cragg, S.; Luo, Y.L.; Lu, C.; Li, Y.; et al. Anthropogenic pressures on coastal wetlands. Front. Ecol. Evol. 2020, 8, 144. [CrossRef]

37. Ouellette, W.; Getinet, W. Remote sensing for marine spatial planning and integrated coastal areas management: Achievements, challenges, opportunities and future prospects. Remote Sens. Appl. Soc. Environ. 2016, 4, 138-157. [CrossRef]

38. Xiao, J.; Chevallier, F.; Gomez, C.; Guanter, L.; Hicke, J.A.; Huete, A.R.; Ichii, K.; Ni, W.; Pang, Y.; Rahman, A.F.; et al. Remote sensing of the terrestrial carbon cycle: A review of advances over 50 years. Remote Sens. Environ. 2019, 233, 111383. [CrossRef]

39. Side, J.; Jowitt, P. Technologies and their influence on future UK marine resource development and management. Mar. Policy 2002, 26, 231-241. [CrossRef]

40. Goetz, A.F.H. Three decades of hyperspectral remote sensing of the earth: A personal view. Remote Sens. Environ. 2009, 113, S5-S16. [CrossRef]

41. Kratzer, S.; Therese Harvey, E.; Philipson, P. The use of ocean color remote sensing in integrated coastal zone management-A case study from Himmerfjärden, Sweden. Mar. Policy 2014, 43, 29-39. [CrossRef]

42. Neukermans, G.; Harmel, T.; Galí, M.; Rudorff, N.; Chowdhary, J.; Dubovik, O.; Hostetler, C.; Hu, Y.; Jamet, C.; Knobelspiesse, K.; et al. Harnessing remote sensing to address critical science questions on ocean-atmosphere interactions. Elementa 2018, 6. [CrossRef]

43. Werdell, P.J.; McKinna, L.I.W.; Boss, E.; Ackleson, S.G.; Craig, S.E.; Gregg, W.W.; Lee, Z.; Maritorena, S.; Roesler, C.S.; Rousseaux, C.S.; et al. An overview of approaches and challenges for retrieving marine inherent optical properties from ocean color remote sensing. Prog. Oceanogr. 2018, 160, 186-212. [CrossRef]

44. Krug, L.A.; Platt, T.; Sathyendranath, S.; Barbosa, A.B. Ocean surface partitioning strategies using ocean colour remote sensing: A review. Prog. Oceanogr. 2017, 155, 41-53. [CrossRef]

45. Toth, C.; Jóźków, G. Remote sensing platforms and sensors: A survey. ISPRS J. Photogramm. Remote Sens. 2016, 115, 22-36. [CrossRef]

46. Zhu, L.; Suomalainen, J.; Liu, J.; Hyyppä, J.; Kaartinen, H.; Haggren, H. A review: Remote sensing sensors. In Multi-Purposeful Application of Geospatial Data; InTechOpen: Rijeka, Croatia, 2018. [CrossRef]

47. Skoog, A.I. The Alfred Nobel rocket camera. An early aerial photography attempt. Acta Astronaut. 2010, 66, 624-635. [CrossRef]

48. Gorman, L.; Morang, A.; Larson, R. Monitoring the coastal environment; Part IV: Mapping, shoreline changes, and bathymetric analysis. J. Coast. Res. 1998, 14, 61-92.

49. Niaounakis, M. Assessment. In Management of Marine Plastic Debris; Elsevier: Amsterdam, The Netherlands, 2017; pp. 143-214. ISBN 978-0-323-44354-8. 
50. Yang, J.; Artigas, F.J. Mapping Salt Marsh Vegetation by Integrating Hyperspectral and LiDAR Remote Sensing; CRC Press: Boca Raton, FL, USA, 2009; pp. 173-187.

51. Klemas, V. Airborne remote sensing of coastal features and processes: An overview. J. Coast. Res. 2012. [CrossRef]

52. Purkis, S.J.; Klemas, V.V. Remote Sensing and Global Environmental Change; John Wiley \& Sons: Hoboken, NJ, USA, 2011; ISBN 1444340255. [CrossRef]

53. Pereira, E.; Bencatel, R.; Correia, J.; Félix, L.; Gonçalves, G.; Morgado, J.; Sousa, J. Unmanned air vehicles for coastal and environmental research. J. Coast. Res. 2009, II, 1557-1561.

54. Klemas, V.V. Coastal and environmental remote sensing from unmanned aerial vehicles: An overview. J. Coast. Res. 2015. [CrossRef]

55. Murfitt, S.L.; Allan, B.M.; Bellgrove, A.; Rattray, A.; Young, M.A.; Ierodiaconou, D. Applications of unmanned aerial vehicles in intertidal reef monitoring. Sci. Rep. 2017, 7, 10259. [CrossRef] [PubMed]

56. Colefax, A.P.; Butcher, P.A.; Kelaher, B.P. The potential for unmanned aerial vehicles (UAVs) to conduct marine fauna surveys in place of manned aircraft. Ices J. Mar. Sci. 2017, 75, 1-8. [CrossRef]

57. Torres, L.G.; Nieukirk, S.L.; Lemos, L.; Chandler, T.E. Drone up! Quantifying whale behavior from a new perspective improves observational capacity. Front. Mar. Sci. 2018, 5, 319. [CrossRef]

58. Papakonstantinou, A.; Topouzelis, K.; Pavlogeorgatos, G. Coastline zones identification and 3D coastal mapping using UAV spatial data. ISPRS Int. J. Geo. Inf. 2016, 5, 75. [CrossRef]

59. Doukari, M.; Batsaris, M.; Papakonstantinou, A.; Topouzelis, K. A Protocol for aerial survey in coastal areas using UAS. Remote Sens. 2019, 11, 1913. [CrossRef]

60. Colomina, I.; Molina, P. Unmanned aerial systems for photogrammetry and remote sensing: A review. ISPRS J. Photogramm. Remote Sens. 2014, 92, 79-97. [CrossRef]

61. Manley, J.E. Unmanned surface vehicles, 15 years of development. In Proceedings of the OCEANS IEEE 2008, Quebec, QC, Canada, 8-11 April 2008; Volume 2008, pp. 1-4.

62. Duarte, M.; Costa, V.; Gomes, J.; Rodrigues, T.; Silva, F.; Oliveira, S.M.; Christensen, A.L. Evolution of collective behaviors for a real swarm of aquatic surface robots. PLoS ONE 2016, 11, e0151834. [CrossRef] [PubMed]

63. Roberts, G.N.; Sutton, R. Advances in Unmanned Marine Vehicles; Roberts, G.N., Sutton, R., Eds.; IET The Institution of Engineering and Technology: Stevenage, UK, 2006; Volume 69, ISBN 9780863414503.

64. Caccia, M.; Bono, R.; Bruzzone, G.; Spirandelli, E.; Veruggio, G.; Stortini, A.M.; Capodaglio, G. Sampling sea surfaces with SESAMO: An autonomous craft for the study of sea-air interactions. IEEE Robot. Autom. Mag. 2005, 12, 95-105. [CrossRef]

65. Naeem, W.; Xu, T.; Sutton, R.; Tiano, A. The design of a navigation, guidance, and control system for an unmanned surface vehicle for environmental monitoring. Proc. Inst. Mech. Eng. Part M J. Eng. Marit. Environ. 2008, 222, 67-79. [CrossRef]

66. Švec, P.; Thakur, A.; Raboin, E.; Shah, B.C.; Gupta, S.K. Target following with motion prediction for unmanned surface vehicle operating in cluttered environments. Auton. Robot. 2014, 36, 383-405. [CrossRef]

67. Leong, S.C.Y.; Tkalich, P.; Patrikalakis, N.M. Monitoring harmful algal blooms in Singapore: Developing a HABs observing system. In Proceedings of the 2012 Oceans-Yeosu IEEE, Yeosu, Korea, 21-24 May 2012; pp. 1-5.

68. Meyer, D. Glider technology for ocean observations: A Review. Ocean Sci. Discuss. 2016, 2016, 1-26. [CrossRef]

69. Ryan, J.P.; Johnson, S.B.; Sherman, A.; Rajan, K.; Py, F.; Thomas, H.; Harvey, J.B.J.; Bird, L.; Paduan, J.D.; Vrijenhoek, R.C. Mobile autonomous process sampling within coastal ocean observing systems. Limnol. Oceanogr. Methods 2010, 8, 394-402. [CrossRef]

70. Verfuss, U.K.; Aniceto, A.S.; Harris, D.V.; Gillespie, D.; Fielding, S.; Jiménez, G.; Johnston, P.; Sinclair, R.R.; Sivertsen, A.; Solbø, S.A.; et al. A review of unmanned vehicles for the detection and monitoring of marine fauna. Mar. Pollut. Bull. 2019, 140, 17-29. [CrossRef]

71. Liu, Z.; Zhang, Y.; Yu, X.; Yuan, C. Unmanned surface vehicles: An overview of developments and challenges. Annu. Rev. Control 2016, 41, 71-93. [CrossRef]

72. Wynn, R.B.; Huvenne, V.A.I.; Le Bas, T.P.; Murton, B.J.; Connelly, D.P.; Bett, B.J.; Ruhl, H.A.; Morris, K.J.; Peakall, J.; Parsons, D.R.; et al. Autonomous Underwater Vehicles (AUVs): Their past, present and future contributions to the advancement of marine geoscience. Mar. Geol. 2014, 352, 451-468. [CrossRef] 
73. Marre, G.; Holon, F.; Luque, S.; Boissery, P.; Deter, J. Monitoring marine habitats with photogrammetry: A cost-effective, accurate, precise and high-resolution reconstruction method. Front. Mar. Sci. 2019, 6, 276. [CrossRef]

74. Katzschmann, R.K.; DelPreto, J.; MacCurdy, R.; Rus, D. Exploration of underwater life with an acoustically controlled soft robotic fish. Sci. Robot. 2018, 3. [CrossRef]

75. Thompson, D.; Caress, D.; Paull, C.; Clague, D.; Thomas, H.; Conlin, D. MBARI mapping AUV operations: In the gulf of California. In Proceedings of the 2012 Oceans IEEE, Hampton Roads, VA, USA, 14-19 October 2012; pp. 1-5. [CrossRef]

76. Allotta, B.; Costanzi, R.; Ridolfi, A.; Colombo, C.; Bellavia, F.; Fanfani, M.; Pazzaglia, F.; Salvetti, O.; Moroni, D.; Pascali, M.A.; et al. The ARROWS project: Adapting and developing robotics technologies for underwater archaeology. IFAC Pap. 2015, 48, 194-199. [CrossRef]

77. Jacobi, M. Autonomous inspection of underwater structures. Robot. Auton. Syst. 2015, 67, 80-86. [CrossRef]

78. Sahoo, A.; Dwivedy, S.K.; Robi, P.S. Advancements in the field of autonomous underwater vehicle. Ocean Eng. 2019, 181, 145-160. [CrossRef]

79. Hu, S.; Wang, H.; Liu, Z.; Wang, Y. Design of a three-dimensional current sensor with measuring upwelling. Flow Meas. Instrum. 2019, 69, 101606. [CrossRef]

80. Parra, L.; Sendra, S.; García, L.; Lloret, J. Design and deployment of low-cost sensors for monitoring the water quality and fish behavior in aquaculture tanks during the feeding process. Sensors 2018, 18, 750. [CrossRef]

81. Barbariol, F.; Benetazzo, A.; Bertotti, L.; Cavaleri, L.; Durrant, T.; McComb, P.; Sclavo, M. Large waves and drifting buoys in the Southern Ocean. Ocean Eng. 2019, 172, 817-828. [CrossRef]

82. Justino, C.I.L.; Freitas, A.C.; Duarte, A.C.; Santos, T.A. Sensors and biosensors for monitoring marine contaminants. Trends Environ. Anal. Chem. 2015, 6-7, 21-30. [CrossRef]

83. Venkatesan, R.; Ramesh, K.; Kishor, A.; Vedachalam, N.; Atmanand, M.A. Best practices for the ocean moored observatories. Front. Mar. Sci. 2018, 5, 469. [CrossRef]

84. McClain, C.R. A Decade of satellite ocean color observations. Ann. Rev. Mar. Sci. 2009, 1, 19-42. [CrossRef]

85. Fretwell, P.T.; Phillips, R.A.; Brooke, M.D.; Fleming, A.H.; McArthur, A. Using the unique spectral signature of guano to identify unknown seabird colonies. Remote Sens. Environ. 2015, 156, 448-456. [CrossRef]

86. Jutz, S.; Milagro-Pérez, M.P. Copernicus program. Compr. Remote Sens. 2018. [CrossRef]

87. Yang, D.; Chen, J.; Zhou, Y.; Chen, X.; Chen, X.; Cao, X. Mapping plastic greenhouse with medium spatial resolution satellite data: Development of a new spectral index. ISPRS J. Photogramm. Remote Sens. 2017, 128, 47-60. [CrossRef]

88. Aguilar, M.; Vallario, A.; Aguilar, F.; Lorca, A.; Parente, C. Object-based greenhouse horticultural crop identification from multi-temporal satellite imagery: A case study in Almeria, Spain. Remote Sens. 2015, 7, 7378-7401. [CrossRef]

89. Wang, D.; Cui, Q.; Gong, F.; Wang, L.; He, X.; Bai, Y. Satellite retrieval of surface water nutrients in the coastal regions of the east China sea. Remote Sens. 2018, 10, 1896. [CrossRef]

90. Blondeau-Patissier, D.; Gower, J.F.R.; Dekker, A.G.; Phinn, S.R.; Brando, V.E. A review of ocean color remote sensing methods and statistical techniques for the detection, mapping and analysis of phytoplankton blooms in coastal and open oceans. Prog. Oceanogr. 2014, 123, 123-144. [CrossRef]

91. Corgne, S.; Hubert-Moy, L.; Betbeder, J. Monitoring of agricultural landscapes using remote sensing data. L. Surf. Remote Sens. Agric. For. 2016. [CrossRef]

92. Liu, C.; Chen, Z.; Shao, Y.; Chen, J.; Hasi, T.; Pan, H. Research advances of SAR remote sensing for agriculture applications: A review. J. Integr. Agric. 2019, 18, 506-525. [CrossRef]

93. Fritz, S.; See, L.; Bayas, J.C.L.; Waldner, F.; Jacques, D.; Becker-Reshef, I.; Whitcraft, A.; Baruth, B.; Bonifacio, R.; Crutchfield, J.; et al. A comparison of global agricultural monitoring systems and current gaps. Agric. Syst. 2019, 168, 258-272. [CrossRef]

94. Beitl, C.M.; Rahimzadeh-Bajgiran, P.; Bravo, M.; Ortega-Pacheco, D.; Bird, K. New valuation for defying degradation: Visualizing mangrove forest dynamics and local stewardship with remote sensing in coastal Ecuador. Geoforum 2019, 98, 123-132. [CrossRef]

95. Kellenberger, B.; Marcos, D.; Tuia, D. Detecting mammals in UAV images: Best practices to address a substantially imbalanced dataset with deep learning. Remote Sens. Environ. 2018, 216, 139-153. [CrossRef] 
96. Chen, J.; Wang, C.; He, D.; Chen, J.; Yue, A. Practical Bottom-Up Golf Course Detection Using Multispectral Remote Sensing Imagery; Zhao, Y., Kong, X., Taubman, D., Eds.; Springer International Publishing: Cham, Switzerland, 2017; pp. 552-559. ISBN 978-3-319-71589-6.

97. Karamvasis, K.; Karathanassi, V. Deformation effects of dams on coastal regions using sentinel-1 iw tops time series: The west Lesvos, Greece case. ISPRS Int. Arch. Photogramm. Remote Sens. Spat. Inf. Sci. 2017. [CrossRef]

98. Ottinger, M.; Clauss, K.; Kuenzer, C. Aquaculture: Relevance, distribution, impacts and spatial assessments-A review. Ocean Coast. Manag. 2016, 119, 244-266. [CrossRef]

99. Bao, J.; Li, D.; Qiao, X.; Rauschenbach, T. Integrated navigation for autonomous underwater vehicles in aquaculture: A review. Inf. Process. Agric. 2019. [CrossRef]

100. Ren, C.; Wang, Z.; Zhang, B.; Li, L.; Chen, L.; Song, K.; Jia, M. Remote monitoring of expansion of aquaculture ponds along coastal region of the Yellow River Delta from 1983 to 2015. Chin. Geogr. Sci. 2018, 28, 430-442. [CrossRef]

101. Le Bris, A.; Rosa, P.; Lerouxel, A.; Cognie, B.; Gernez, P.; Launeau, P.; Robin, M.; Barillé, L. Hyperspectral remote sensing of wild oyster reefs. Estuar. Coast. Shelf Sci. 2016, 172, 1-12. [CrossRef]

102. Klemas, V. Fisheries applications of remote sensing: An overview. Fish. Res. 2013, 148, 124-136. [CrossRef]

103. Heumann, B.W.; Hackett, R.A.; Monfils, A.K.; Gross, J.W. The Remote sensing of biodiversity: From global to local scales. Compr. Remote Sens. 2018. [CrossRef]

104. Chaussard, E.; Kerosky, S. Characterization of black sand mining activities and their environmental impacts in the philippines using remote sensing. Remote Sens. 2016, 8, 100. [CrossRef]

105. Werner, T.T.; Bebbington, A.; Gregory, G. Assessing impacts of mining: Recent contributions from GIS and remote sensing. Extr. Ind. Soc. 2019, 6, 993-1012. [CrossRef]

106. Miller, M.L.; Lieske, S.N.; Carter, R.W.; Walsh, S.J. Understanding the interaction between a protected destination system and conservation tourism through remote sensing. Compr. Remote Sens. 2018. [CrossRef]

107. Wolf, N.; Hof, A. Integrating machine learning techniques and high-resolution imagery to generate GIS-ready information for urban water consumption studies. In Proceedings of the Earth Resources and Environmental Remote Sensing/GIS Applications III 2012, Edinburgh, UK, 25 October 2012; Volume 8538.

108. Llausàs, A.; Hof, A.; Wolf, N.; Saurí, D.; Siegmund, A. Applicability of cadastral data to support the estimation of water use in private swimming pools. Environ. Plan. B Urban Anal. City Sci. 2018, 46, 1165-1181. [CrossRef]

109. Cabezas-Rabadán, C.; Pardo-Pascual, J.E.; Almonacid-Caballer, J.; Rodilla, M. Detecting problematic beach widths for the recreational function along the Gulf of Valencia (Spain) from Landsat 8 subpixel shorelines. Appl. Geogr. 2019, 110, 102047. [CrossRef]

110. Cabezas-Rabadán, C.; Pardo-Pascual, J.E.; Palomar-Vázquez, J.; Fernández-Sarría, A. Characterizing beach changes using high-frequency Sentinel-2 derived shorelines on the Valencian coast (Spanish Mediterranean). Sci. Total Environ. 2019, 691, 216-231. [CrossRef] [PubMed]

111. Chen, B.; Yang, Y.; Wen, H.; Ruan, H.; Zhou, Z.; Luo, K.; Zhong, F. High-resolution monitoring of beach topography and its change using unmanned aerial vehicle imagery. Ocean Coast. Manag. 2018, 160, $103-116$. [CrossRef]

112. Sung, C.Y.; Cho, W.; Hong, S.-H. Estimating the annual carbon budget of a weekend tourist resort in a temperate secondary forest in Korea. Urban For. Urban Green. 2015, 14, 413-419. [CrossRef]

113. Al Shehhi, M.R.; Gherboudj, I.; Ghedira, H. Satellites-based monitoring of harmful algal blooms for sustainable desalination. In Desalination Sustainability; Elsevier: Amsterdam, The Netherlands, 2017; pp. 341-366. ISBN 9780128098967.

114. Al Muhairi, A.; Ghedira, H.; Al-Ahmad, H.; Dawood, A.; Al-Mualla, M. Exploring the potential of MODIS visible and thermal channels in monitoring and assessing the impact of desalination plant discharges in the Arabian Gulf. In Proceedings of the 2009 IEEE International Geoscience and Remote Sensing Symposium, Cape Town, South Africa, 12-17 July 2009; Volume 3, pp. 357-360.

115. Yuan, Y.; Jalón-Rojas, I.; Wang, X.H. Impact of coastal infrastructure on ocean colour remote sensing: A case study in Jiaozhou Bay, China. Remote Sens. 2019, 11, 946. [CrossRef]

116. Klein, M.; Zviely, D. The environmental impact of marina development on adjacent beaches: A case study of the Herzliya marina, Israel. Appl. Geogr. 2001, 21, 145-156. [CrossRef] 
117. Merico, E.; Dinoi, A.; Contini, D. Development of an integrated modelling-measurement system for near-real-time estimates of harbour activity impact to atmospheric pollution in coastal cities. Transp. Res. Part D Transp. Environ. 2019, 73, 108-119. [CrossRef]

118. Hellweger, F.L.; Schlosser, P.; Lall, U.; Weissel, J.K. Use of satellite imagery for water quality studies in New York Harbor. Estuar. Coast. Shelf Sci. 2004, 61, 437-448. [CrossRef]

119. Gracia, V.; Sierra, J.P.; Gómez, M.; Pedrol, M.; Sampé, S.; García-León, M.; Gironella, X. Assessing the impact of sea level rise on port operability using LiDAR-derived digital elevation models. Remote Sens. Environ. 2019, 232, 111318. [CrossRef]

120. Vos, K.; Harley, M.D.; Splinter, K.D.; Simmons, J.A.; Turner, I.L. Sub-annual to multi-decadal shoreline variability from publicly available satellite imagery. Coast. Eng. 2019, 150, 160-174. [CrossRef]

121. Caballero, I.; Navarro, G.; Ruiz, J. Multi-platform assessment of turbidity plumes during dredging operations in a major estuarine system. Int. J. Appl. Earth Obs. Geoinf. 2018, 68, 31-41. [CrossRef]

122. Kanjir, U.; Greidanus, H.; Oštir, K. Vessel detection and classification from spaceborne optical images: A literature survey. Remote Sens. Environ. 2018, 207, 1-26. [CrossRef] [PubMed]

123. Xiao, C.; Sun, D.; Wang, S.; Qiu, Z.; Huan, Y.; Zhang, J. Long-term changes in colored dissolved organic matter from satellite observations in the Bohai Sea and North Yellow Sea. Remote Sens. 2018, 10, 688. [CrossRef]

124. Hasager, C.B. Offshore winds mapped from satellite remote sensing. Wiley Interdiscip. Rev. Energy Environ. 2014, 3, 594-603. [CrossRef]

125. Shukla, A.; Karki, H. Application of robotics in offshore oil and gas industry-A review Part II. Robot. Auton. Syst. 2016, 75, 508-524. [CrossRef]

126. Liu, Y.; Hu, C.; Sun, C.; Zhan, W.; Sun, S.; Xu, B.; Dong, Y. Assessment of offshore oil/gas platform status in the northern Gulf of Mexico using multi-source satellite time-series images. Remote Sens. Environ. 2018, 208, 63-81. [CrossRef]

127. Dai, X.; Guo, Z.; Lin, Y.; Wei, C.; Ye, S. Application of satellite remote sensing data for monitoring thermal discharge pollution from Tianwan nuclear power plant in eastern China. In Proceedings of the 20125 th International Congress on Image and Signal Processing IEEE, Chongqing, China, 16-18 October 2012; pp. 1019-1023.

128. Litynski, J.; Vikara, D.; Webster, M.; Srivastava, R.U.S. Department of energy efforts to advance remote sensing technologies for monitoring geologic storage operations. Energy Procedia 2013, 37, 4114-4127. [CrossRef]

129. Luo, L.; Wang, X.; Guo, H.; Lasaponara, R.; Zong, X.; Masini, N.; Wang, G.; Shi, P.; Khatteli, H.; Chen, F.; et al. Airborne and spaceborne remote sensing for archaeological and cultural heritage applications: A review of the century (1907-2017). Remote Sens. Environ. 2019, 232, 111280. [CrossRef]

130. Erten, E.; Rossi, C. The worsening impacts of land reclamation assessed with Sentinel-1: The Rize (Turkey) test case. Int. J. Appl. Earth Obs. Geoinf. 2019, 74, 57-64. [CrossRef]

131. Smith, L.; Cornillon, P.; Rudnickas, D.; Mouw, C.B. Evidence of Environmental changes caused by Chinese island-building. Sci. Rep. 2019, 9, 5295. [CrossRef] [PubMed]

132. Beck, A.J.; Gledhill, M.; Schlosser, C.; Stamer, B.; Böttcher, C.; Sternheim, J.; Greinert, J.; Achterberg, E.P. Spread, behavior, and ecosystem consequences of conventional munitions compounds in coastal marine waters. Front. Mar. Sci. 2018, 5, 141. [CrossRef]

133. Campbell, B.M.; Beare, D.J.; Bennett, E.M.; Hall-Spencer, J.M.; Ingram, J.S.I.; Jaramillo, F.; Ortiz, R.; Ramankutty, N.; Sayer, J.A.; Shindell, D. Agriculture production as a major driver of the Earth system exceeding planetary boundaries. Ecol. Soc. 2017, 22. [CrossRef]

134. Huang, Y.; Chen, Z.; Yu, T.; Huang, X.; Gu, X. Agricultural remote sensing big data: Management and applications. J. Integr. Agric. 2018, 17, 1915-1931. [CrossRef]

135. Mattsson, E.; Ostwald, M.; Nissanka, S.P.; Holmer, B.; Palm, M. Recovery and protection of coastal ecosystems after tsunami event and potential for participatory forestry CDM-Examples from Sri Lanka. Ocean Coast. Manag. 2009, 52, 1-9. [CrossRef]

136. Salgot, M.; Tapias, J.C. Golf courses: Environmental impacts. Tour. Hosp. Res. 2006, 6, 218-226. [CrossRef]

137. Syvitski, J.P.M.; Kettner, A. Sediment flux and the Anthropocene. Philos. Trans. R. Soc. A Math. Phys. Eng. Sci. 2011, 369, 957-975. [CrossRef]

138. Milliman, J.D. Blessed dams or damned dams? Nature 1997, 386, 325-327. [CrossRef] 
139. Ezcurra, E.; Barrios, E.; Ezcurra, P.; Ezcurra, A.; Vanderplank, S.; Vidal, O.; Villanueva-Almanza, L.; Aburto-Oropeza, O. A natural experiment reveals the impact of hydroelectric dams on the estuaries of tropical rivers. Sci. Adv. 2019, 5. [CrossRef]

140. FAO. The State of World Fisheries and Aquaculture 2018-Meeting the Sustainable Development Goals; FAO: Rome, Italy, 2018.

141. EU. Report on the Blue Growth Strategy-Towards More Sustainable Growth and Jobs in the Blue Economy; European Union: Brussels, Belgium, 2017.

142. Singh, S.; Parida, B. Satellite-based identification of aquaculture farming over coastal areas around Bhitarkanika, Odisha using a neural network method. Proceedings 2018, 2, 331. [CrossRef]

143. Bostock, J.; McAndrew, B.; Richards, R.; Jauncey, K.; Telfer, T.; Lorenzen, K.; Little, D.; Ross, L.; Handisyde, N.; Gatward, I.; et al. Aquaculture: Global status and trends. Philos. Trans. R. Soc. B Biol. Sci. 2010, 365, 2897-2912. [CrossRef]

144. Troell, M.; Kautsky, N.; Beveridge, M.; Henriksson, P.; Primavera, J.; Rönnbäck, P.; Folke, C. Aquaculture. Encycl. Biodivers. 2013. [CrossRef]

145. Espmark, Å.M.; Kolarevic, J.; Åsgård, T.; Terjesen, B.F. Tank size and fish management history matters in experimental design. Aquac. Res. 2017, 48, 2876-2894. [CrossRef]

146. Prasad, K.; Ottinger, M.; Wei, C.; Leinenkugel, P. Assessment of coastal aquaculture for india from sentinel-1 SAR time series. Remote Sens. 2019, 11, 357. [CrossRef]

147. Laurs, R.M.; Foley, D.; Musyl, M. Identification of large pelagic marine fish habitats and habitat utilization using 'pop-up' satellite archival tag and oceanic satellite remote sensing technologies and 'SODA' simple ocean data simulation model analyses. In Proceedings of the 2006 IEEE US/EU Baltic International Symposium, Klaipeda, Lithuania, 23-26 May 2006; pp. 1-9.

148. Elvidge, C.D.; Ghosh, T.; Baugh, K.; Zhizhin, M.; Hsu, F.-C.; Katada, N.S.; Penalosa, W.; Hung, B.Q. Rating the effectiveness of fishery closures with visible infrared imaging radiometer suite boat detection data. Front. Mar. Sci. 2018, 5, 132. [CrossRef]

149. Jonah, F.E.; Adjei-Boateng, D.; Agbo, N.W.; Mensah, E.A.; Edziyie, R.E. Assessment of sand and stone mining along the coastline of Cape Coast, Ghana. Ann. Gis. 2015, 21, 223-231. [CrossRef]

150. Jackson, N.L.; Nordstrom, K.F. Trends in research on beaches and dunes on sandy shores, 1969-2019. Geomorphology 2019. [CrossRef]

151. Prodger, S.; Russell, P.; Davidson, M.; Miles, J.; Scott, T. Understanding and predicting the temporal variability of sediment grain size characteristics on high-energy beaches. Mar. Geol. 2016, 376, 109-117. [CrossRef]

152. Palmer, A.; Mathel, V. Causes and consequences of underutilised capacity in a tourist resort development. Tour. Manag. 2010, 31, 925-935. [CrossRef]

153. Anderson, D.M.; Boerlage, S.F.E.; Dixon, M.B. Harmful Algal Blooms (HABs) and desalination: A Guide to impacts, monitoring, and management. Filtr. Ind. Anal. 2017, 2017, 4. [CrossRef]

154. Trees, C.C.; Bissett, P.W.; Dierssen, H.; Kohler, D.D.R.; Moline, M.A.; Mueller, J.L.; Pieper, R.E.; Twardowski, M.S.; Zaneveld, J.R.V. Monitoring water transparency and diver visibility in ports and harbors using aircraft hyperspectral remote sensing. In Proceedings of the SPIE, Photonics for port and Harbor Security, Orlando, FL, USA, 19 May 2005; Volume 5780, p. 91. [CrossRef]

155. Danovaro, R.; Nepote, E.; Martire, M.L.; Ciotti, C.; De Grandis, G.; Corinaldesi, C.; Carugati, L.; Cerrano, C.; Pica, D.; Di Camillo, C.G.; et al. Limited impact of beach nourishment on macrofaunal recruitment/settlement in a site of community interest in coastal area of the Adriatic Sea (Mediterranean Sea). Mar. Pollut. Bull. 2018, 128, 259-266. [CrossRef] [PubMed]

156. Semeoshenkova, V.; Newton, A. Overview of erosion and beach quality issues in three Southern European countries: Portugal, Spain and Italy. Ocean Coast. Manag. 2015, 118, 12-21. [CrossRef]

157. Pranzini, E.; Anfuso, G.; Botero, C.-M.; Cabrera, A.; Apin Campos, Y.; Casas Martinez, G.; Williams, A.T. Sand colour at Cuba and its influence on beach nourishment and management. Ocean Coast. Manag. 2016, 126, 51-60. [CrossRef]

158. Erftemeijer, P.L.A.; Riegl, B.; Hoeksema, B.W.; Todd, P.A. Environmental impacts of dredging and other sediment disturbances on corals: A review. Mar. Pollut. Bull. 2012, 64, 1737-1765. [CrossRef] [PubMed]

159. An, H.; Choi, S.; Lee, J.H. Integrated scheduling of vessel dispatching and port operations in the closed-loop shipping system for transporting petrochemicals. Comput. Chem. Eng. 2019, 126, 485-498. [CrossRef] 
160. Weiss, C.V.C.; Guanche, R.; Ondiviela, B.; Castellanos, O.F.; Juanes, J. Marine renewable energy potential: A global perspective for offshore wind and wave exploitation. Energy Convers. Manag. 2018, 177, 43-54. [CrossRef]

161. Calaudi, R.; Feudo, T.L.; Calidonna, C.R.; Sempreviva, A.M. Using remote sensing data for integrating different renewable energy sources at coastal site in south Italy. Energy Procedia 2016, 97, 172-178. [CrossRef]

162. Schwanitz, V.J.; Wierling, A.; Shah, P. Assessing the impact of renewable energy on regional sustainability-A comparative study of Sogn og Fjordane (Norway) and Okinawa (Japan). Sustainability 2017, 9, 1969. [CrossRef]

163. Necci, A.; Tarantola, S.; Vamanu, B.; Krausmann, E.; Ponte, L. Lessons learned from offshore oil and gas incidents in the Arctic and other ice-prone seas. Ocean Eng. 2019, 185, 12-26. [CrossRef]

164. Hejazi, R. Nuclear energy: Sense or nonsense for environmental challenges. Int. J. Sustain. Built Environ. 2017, 6, 693-700. [CrossRef]

165. Zhang, S.; Zhuang, Y.; Liu, L.; Zhang, L.; Du, J. Risk management optimization framework for the optimal deployment of carbon capture and storage system under uncertainty. Renew. Sustain. Energy Rev. 2019, 113, 109280. [CrossRef]

166. Benjamin, J.; McCarthy, J.; Wiseman, C.; Bevin, S.; Kowlessar, J.; Astrup, P.M.; Naumann, J.; Hacker, J. Integrating aerial and underwater data for archaeology: Digital maritime landscapes in 3D. In 3D Recording and Interpretation for Maritime Archaeology; McCarthy, J.K., Benjamin, J., Winton, T., Van Duivenvoorde, W., Eds.; Springer International Publishing: Cham, Switzerland, 2019; pp. 211-231. ISBN 978-3-030-03635-5.

167. Tapete, D. Remote sensing and geosciences for archaeology. Geosciences 2018, 8, 41. [CrossRef]

168. McCoy, M. The Race to document archaeological sites ahead of rising sea levels: Recent applications of geospatial technologies in the archaeology of polynesia. Sustainability 2018, 10, 185. [CrossRef]

169. Duan, H.; Zhang, H.; Huang, Q.; Zhang, Y.; Hu, M.; Niu, Y.; Zhu, J. Characterization and environmental impact analysis of sea land reclamation activities in China. Ocean Coast. Manag. 2016, 130, 128-137. [CrossRef]

170. Martín-Antón, M.; Negro, V.; Del Campo, J.M.; López-Gutiérrez, J.S.; Esteban, M.D. Review of coastal land reclamation situation in the World. J. Coast. Res. 2016, 75, 667-671. [CrossRef]

171. Zhang, J.; Su, F.; Ding, Z. Sea Reclamation status of countries around the South China Sea from 1975 to 2010. Sustainability 2017, 9, 878. [CrossRef]

172. Chen, W.; Wang, D.; Huang, Y.; Chen, L.; Zhang, L.; Wei, X.; Sang, M.; Wang, F.; Liu, J.; Hu, B. Monitoring and analysis of coastal reclamation from 1995-2015 in Tianjin Binhai New Area, China. Sci. Rep. 2017, 7, 3850. [CrossRef]

173. Doxaran, D.; Bustamante, J.; Dogliotti, A.I.; Malthus, T.J.; Senechal, N. Editorial for the Special Issue Remote sensing in coastal zone monitoring and management-How can remote sensing challenge the broad spectrum of temporal and spatial scales in coastal zone dynamic? Remote Sens. 2019, 11, 1028. [CrossRef]

174. Splinter, K.; Harley, M.; Turner, I. Remote sensing is changing our view of the coast: Insights from 40 years of monitoring at Narrabeen-Collaroy, Australia. Remote Sens. 2018, 10, 1744. [CrossRef]

175. Newton, A.; Carruthers, T.J.B.; Icely, J. The coastal syndromes and hotspots on the coast. Estuar. Coast. Shelf Sci. 2012, 96, 39-47. [CrossRef]

176. Churnside, J.H.; Naugolnykh, K.; Marchbanks, R.D. Optical remote sensing of sound in the ocean. Ocean Sens. Monit. VI 2014. [CrossRef]

177. Soares, C.; Pacheco, A.; Zabel, F.; González-Goberña, E.; Sequeira, C. Baseline assessment of underwater noise in the Ria Formosa. Mar. Pollut. Bull. 2019. [CrossRef] [PubMed]

178. Cunning, R.; Silverstein, R.N.; Barnes, B.B.; Baker, A.C. Extensive coral mortality and critical habitat loss following dredging and their association with remotely-sensed sediment plumes. Mar. Pollut. Bull. 2019, 145, 185-199. [CrossRef]

179. Maximenko, N.; Corradi, P.; Law, K.L.; Van Sebille, E.; Garaba, S.P.; Lampitt, R.S.; Galgani, F.; Martinez-Vicente, V.; Goddijn-Murphy, L.; Veiga, J.M.; et al. Toward the integrated marine debris observing system. Front. Mar. Sci. 2019, 6, 447. [CrossRef]

180. Garaba, S.P.; Aitken, J.; Slat, B.; Dierssen, H.M.; Lebreton, L.; Zielinski, O.; Reisser, J. Sensing ocean plastics with an airborne hyperspectral shortwave infrared imager. Environ. Sci. Technol. 2018, 52, 11699-11707. [CrossRef] 
181. Bao, Z.; Sha, J.; Li, X.; Hanchiso, T.; Shifaw, E. Monitoring of beach litter by automatic interpretation of unmanned aerial vehicle images using the segmentation threshold method. Mar. Pollut. Bull. 2018, 137, 388-398. [CrossRef]

182. Martin, C.; Parkes, S.; Zhang, Q.; Zhang, X.; McCabe, M.F.; Duarte, C.M. Use of unmanned aerial vehicles for efficient beach litter monitoring. Mar. Pollut. Bull. 2018, 131, 662-673. [CrossRef]

183. Fallati, L.; Polidori, A.; Salvatore, C.; Saponari, L.; Savini, A.; Galli, P. Anthropogenic marine debris assessment with unmanned aerial vehicle imagery and deep learning: A case study along the beaches of the Republic of Maldives. Sci. Total Environ. 2019, 693, 133581. [CrossRef]

184. Acuña-Ruz, T.; Uribe, D.; Taylor, R.; Amézquita, L.; Guzmán, M.C.; Merrill, J.; Martínez, P.; Voisin, L.; Mattar, B.C. Anthropogenic marine debris over beaches: Spectral characterization for remote sensing applications. Remote Sens. Environ. 2018, 217, 309-322. [CrossRef]

185. Moy, K.; Neilson, B.; Chung, A.; Meadows, A.; Castrence, M.; Ambagis, S.; Davidson, K. Mapping coastal marine debris using aerial imagery and spatial analysis. Mar. Pollut. Bull. 2018, 132, 52-59. [CrossRef] [PubMed]

186. Mancini, S.; Olsen, R.C.; Abileah, R.; Lee, K.R. Automating nearshore bathymetry extraction from wave motion in satellite optical imagery. In Proceedings of the SPIE, Algorithms and Technologies for Multispectral, and Ultraspectral Imagery XVIII, Baltimore, MD, USA, 14 May 2012; Volume 8390, p. 83900P.

187. Toure, S.; Diop, O.; Kpalma, K.; Maiga, A. Shoreline detection using optical remote sensing: A Review. ISPRS Int. J. Geo. Inf. 2019, 8, 75. [CrossRef]

188. Zhao, J.; Temimi, M.; Ghedira, H. Remotely sensed sea surface salinity in the hyper-saline Arabian Gulf: Application to landsat 8 OLI data. Estuar. Coast. Shelf Sci. 2017, 187, 168-177. [CrossRef]

189. Kao, H.-Y.; Lagerloef, G.; Lee, T.; Melnichenko, O.; Meissner, T.; Hacker, P. Assessment of Aquarius Sea surface salinity. Remote Sens. 2018, 10, 1341. [CrossRef]

190. Fingas, M.; Brown, C.E. A Review of oil spill remote sensing. Sensors 2017, 18, 91. [CrossRef]

191. Odonkor, P.; Ball, Z.; Chowdhury, S. Distributed operation of collaborating unmanned aerial vehicles for time-sensitive oil spill mapping. Swarm Evol. Comput. 2019, 46, 52-68. [CrossRef]

192. Zhu, G.; Xie, Z.; Li, T.; Ma, Z.; Xu, X. Assessment ecological risk of heavy metal caused by high-intensity land reclamation in Bohai Bay, China. PLoS ONE 2017, 12, e0175627. [CrossRef]

193. Wang, X.; Zhang, F.; Kung, H.; Johnson, V.C. New methods for improving the remote sensing estimation of soil organic matter content (SOMC) in the Ebinur Lake Wetland National Nature Reserve (ELWNNR) in northwest China. Remote Sens. Environ. 2018, 218, 104-118. [CrossRef]

194. Han, M.; Pan, B.; Liu, Y.B.; Yu, H.Z.; Liu, Y.R. Wetland biomass inversion and space differentiation: A case study of the Yellow River Delta Nature Reserve. PLoS ONE 2019, 14, e210774. [CrossRef]

195. Zhai, M. Inversion of organic matter content in wetland soil based on Landsat 8 remote sensing image. J. Vis. Commun. Image Represent. 2019, 64, 102645. [CrossRef]

196. Juhls, B.; Overduin, P.P.; Hölemann, J.; Hieronymi, M.; Matsuoka, A.; Heim, B.; Fischer, J. Dissolved organic matter at the fluvial-marine transition in the Laptev Sea using in situ data and ocean colour remote sensing. Biogeosciences 2019, 16, 2693-2713. [CrossRef]

197. Connor, D.; Martin, P.G.; Scott, T.B. Airborne radiation mapping: Overview and application of current and future aerial systems. Int. J. Remote Sens. 2016, 37, 5953-5987. [CrossRef]

198. Kaiser, M.F.; Aziz, A.M.; Ghieth, B.M. Environmental hazards and distribution of radioactive black sand along the Rosetta coastal zone in Egypt using airborne spectrometric and remote sensing data. J. Environ. Radioact. 2014, 137, 71-78. [CrossRef] [PubMed]

199. Martin, P.; Moore, J.; Fardoulis, J.; Payton, O.; Scott, T. Radiological assessment on interest areas on the Sellafield nuclear site via unmanned aerial vehicle. Remote Sens. 2016, 8, 913. [CrossRef]

200. Ma, P.; Dai, X.; Guo, Z.; Wei, C.; Ma, W. Detection of thermal pollution from power plants on China's eastern coast using remote sensing data. Stoch. Environ. Res. Risk Assess. 2017, 31, 1957-1975. [CrossRef]

201. D'Angelo, C.; Wiedenmann, J. Impacts of nutrient enrichment on coral reefs: New perspectives and implications for coastal management and reef survival. Curr. Opin. Environ. Sustain. 2014, 7, 82-93. [CrossRef] 
202. Newton, A.; Icely, J.; Cristina, S.; Brito, A.; Cardoso, A.C.; Colijn, F.; Riva, S.D.; Gertz, F.; Hansen, J.W.; Holmer, M.; et al. An overview of ecological status, vulnerability and future perspectives of European large shallow, semi-enclosed coastal systems, lagoons and transitional waters. Estuar. Coast. Shelf Sci. 2014, 140, 95-122. [CrossRef]

203. Arteaga, L.; Pahlow, M.; Oschlies, A. Global monthly sea surface nitrate fields estimated from remotely sensed sea surface temperature, chlorophyll, and modeled mixed layer depth. Geophys. Res. Lett. 2015, 42, 1130-1138. [CrossRef]

204. Borja, Á.; Elliott, M. Marine monitoring during an economic crisis: The cure is worse than the disease. Mar. Pollut. Bull. 2013, 68, 1-3. [CrossRef]

205. Borja, A.; Elliott, M. So when will we have enough papers on microplastics and ocean litter? Mar. Pollut. Bull. 2019, 146, 312-316. [CrossRef]

206. Moller, D.; Chao, Y.; Maximenko, N. Remote sensing of marine debris. In Proceedings of the 2016 IEEE International Geoscience and Remote Sensing Symposium (IGARSS), Beijing, China, 10-15 July 2016; pp. 7690-7693.

207. Addamo, A.M.; Brosich, A.; Chaves, M.D.M.; Giorgetti, A.; Hanke, G.; Molina, E. Marine Litter Database: Lessons Learned in Compiling the First Pan-European Beach Litter Database, EUR 29469 EN; Publications Office of the European Union: Luxembourg, 2018.

208. Goddijn-Murphy, L.; Peters, S.; Van Sebille, E.; James, N.A.; Gibb, S. Concept for a hyperspectral remote sensing algorithm for floating marine macro plastics. Mar. Pollut. Bull. 2018, 126, 255-262. [CrossRef] [PubMed]

209. Bao, S.; Wang, H.; Zhang, R.; Yan, H.; Chen, J. Comparison of satellite-derived sea surface salinity products from SMOS, Aquarius, and SMAP. J. Geophys. Res. Ocean. 2019, 124, 1932-1944. [CrossRef]

210. Fingas, M.; Brown, C.E. Oil spill remote sensing: A Review. Oil Spill Sci. Technol. 2011. [CrossRef]

211. Fingas, M.; Brown, C. Review of oil spill remote sensing. Mar. Pollut. Bull. 2014, 83, 9-23. [CrossRef]

212. Bayramov, E.; Bayramov, R.; Aliyeva, S. Optical and radar remote sensing and contamination probability modelling for the advanced quantitative risk assessment of marine petroleum and gas industry. IFAC Pap. 2018, 51, 31-33. [CrossRef]

213. Alpers, W.; Holt, B.; Zeng, K. Oil spill detection by imaging radars: Challenges and pitfalls. Remote Sens. Environ. 2017, 201, 133-147. [CrossRef]

214. Fingas, M. The Challenges of remotely measuring oil slick thickness. Remote Sens. 2018, 10, 319. [CrossRef]

215. Sharifuzzaman, S.M.; Rahman, H.; Ashekuzzaman, S.M.; Islam, M.M.; Chowdhury, S.R.; Hossain, M.S. Heavy Metals Accumulation in Coastal Sediments BT-Environmental Remediation Technologies for Metal-Contaminated Soils; Hasegawa, H., Rahman, I.M.M., Rahman, M.A., Eds.; Springer: Japan, Tokyo, 2016; pp. 21-42. ISBN 978-4-431-55759-3.

216. Deininger, A.; Frigstad, H. Reevaluating the role of organic matter sources for coastal eutrophication, oligotrophication, and ecosystem health. Front. Mar. Sci. 2019, 6, 210. [CrossRef]

217. Findlay, S.E.G.; Parr, T.B. Dissolved organic matter. Methods Stream Ecol. 2017. [CrossRef]

218. Nezlin, N.P.; Beegan, C.; Feit, A.; Gully, J.R.; Latker, A.; McLaughlin, K.; Mengel, M.J.; Robertson, G.L.; Steele, A.; Weisberg, S.B. Colored Dissolved Organic Matter (CDOM) as a tracer of effluent plumes in the coastal ocean. Reg. Stud. Mar. Sci. 2020, 35, 101163. [CrossRef]

219. Aurin, D.A.; Dierssen, H.M. Advantages and limitations of ocean color remote sensing in CDOM-dominated, mineral-rich coastal and estuarine waters. Remote Sens. Environ. 2012, 125, 181-197. [CrossRef]

220. Cao, F.; Tzortziou, M.; Hu, C.; Mannino, A.; Fichot, C.G.; Del Vecchio, R.; Najjar, R.G.; Novak, M. Remote sensing retrievals of colored dissolved organic matter and dissolved organic carbon dynamics in North American estuaries and their margins. Remote Sens. Environ. 2018, 205, 151-165. [CrossRef]

221. Uddin, S.; Behbehani, M. Concentrations of selected radionuclides and their spatial distribution in marine sediments from the northwestern Gulf, Kuwait. Mar. Pollut. Bull. 2018, 127, 73-81. [CrossRef]

222. El-Saharty, A.A. Radioactive survey of coastal water and sediments across Alexandria and Rashid coasts. Egypt. J. Aquat. Res. 2013, 39, 21-30. [CrossRef]

223. Chen, C.; Shi, P.; Mao, Q. Application of remote sensing techniques for monitoring the thermal pollution of cooling-water discharge from nuclear power plant. J. Environ. Sci. Health Part A 2003, 38, 1659-1668. [CrossRef] [PubMed] 
224. Gholizadeh, M.H.; Melesse, A.M.; Reddi, L. A Comprehensive review on water quality parameters estimation using remote sensing techniques. Sensors 2016, 16, 1298. [CrossRef] [PubMed]

225. Choi, J.-K.; Park, Y.J.; Ahn, J.H.; Lim, H.-S.; Eom, J.; Ryu, J.-H. GOCI, the world's first geostationary ocean color observation satellite, for the monitoring of temporal variability in coastal water turbidity. J. Geophys. Res. Ocean. 2012, 117. [CrossRef]

226. He, X.; Bai, Y.; Pan, D.; Huang, N.; Dong, X.; Chen, J.; Chen, C.-T.A.; Cui, Q. Using geostationary satellite ocean color data to map the diurnal dynamics of suspended particulate matter in coastal waters. Remote Sens. Environ. 2013, 133, 225-239. [CrossRef]

227. Pham, T.D.; Xia, J.; Ha, N.T.; Bui, D.T.; Le, N.N.; Tekeuchi, W. A Review of remote sensing approaches for monitoring blue carbon ecosystems: Mangroves, seagrassesand salt marshes during 2010-2018. Sensors 2019, 19, 1933. [CrossRef]

228. Wang, L.; Jia, M.; Yin, D.; Tian, J. A review of remote sensing for mangrove forests: 1956-2018. Remote Sens. Environ. 2019, 231, 111223. [CrossRef]

229. Phinn, S.; Roelfsema, C.; Kovacs, E.; Canto, R.; Lyons, M.; Saunders, M.; Maxwell, P. Mapping, Monitoring and Modelling Seagrass Using Remote Sensing Techniques BT-Seagrasses of Australia: Structure, Ecology and Conservation; Larkum, A.W.D., Kendrick, G.A., Ralph, P.J., Eds.; Springer International Publishing: Cham, Switzerland, 2018; pp. 445-487. ISBN 978-3-319-71354-0.

230. Hedley, J.; Roelfsema, C.; Chollett, I.; Harborne, A.; Heron, S.; Weeks, S.; Skirving, W.; Strong, A.; Eakin, C.; Christensen, T.; et al. Remote sensing of coral reefs for monitoring and management: A Review. Remote Sens. 2016, 8, 118. [CrossRef]

231. Favretto, A. Checking vegetation changes with remote sensing: The case of the Trieste province (North-East of Italy). Remote Sens. Appl. Soc. Environ. 2018, 11, 1-10. [CrossRef]

232. Kemper, G.; Weidauer, A.; Coppack, T. Monitoring seabirds and marine mammals by georeferenced aerial photography. Int. Arch. Photogramm. Remote Sens. Spat. Inf. Sci. 2016, 41, 689-694. [CrossRef]

233. Coleman, A.T.; Pitchford, J.L.; Bailey, H.; Solangi, M. Seasonal movements of immature Kemp's ridley sea turtles (Lepidochelys kempii) in the northern gulf of Mexico. Aquat. Conserv. Mar. Freshw. Ecosyst. 2017, 27, 253-267. [CrossRef]

234. Williamson, M.J.; Tebbs, E.J.; Dawson, T.P.; Jacoby, D.M.P. Satellite remote sensing in shark and ray ecology, conservation and management. Front. Mar. Sci. 2019, 6, 135. [CrossRef]

235. Rengstorf, A.M.; Mohn, C.; Brown, C.; Wisz, M.S.; Grehan, A.J. Predicting the distribution of deep-sea vulnerable marine ecosystems using high-resolution data: Considerations and novel approaches. Deep Sea Res. Part I Oceanogr. Res. Pap. 2014, 93, 72-82. [CrossRef]

236. Minnett, P.J.; Alvera-Azcárate, A.; Chin, T.M.; Corlett, G.K.; Gentemann, C.L.; Karagali, I.; Li, X.; Marsouin, A.; Marullo, S.; Maturi, E.; et al. Half a century of satellite remote sensing of sea-surface temperature. Remote Sens. Environ. 2019, 233, 111366. [CrossRef]

237. Carrasco, R.; Horstmann, J.; Seemann, J. Significant wave height measured by coherent X-band radar. IEEE Trans. Geosci. Remote Sens. 2017, 55, 5355-5365. [CrossRef]

238. Mateos, R.M.; Azañón, J.M.; Roldán, F.J.; Notti, D.; Pérez-Peña, V.; Galve, J.P.; Pérez-García, J.L.; Colomo, C.M.; Gómez-López, J.M.; Montserrat, O.; et al. The combined use of PSInSAR and UAV photogrammetry techniques for the analysis of the kinematics of a coastal landslide affecting an urban area (SE Spain). Landslides 2017, 14, 743-754. [CrossRef]

239. Cian, F.; Blasco, J.; Carrera, L. Sentinel-1 for monitoring land subsidence of coastal cities in Africa Using PSInSAR: A Methodology based on the integration of SNAP and StaMPS. Geosciences 2019, 9, 124. [CrossRef]

240. Zhang, R.; Chen, L.; Liu, S.; Zhang, H.; Gong, W.; Lin, G. Shoreline evolution in an embayed beach adjacent to tidal inlet: The impact of anthropogenic activities. Geomorphology 2019, 346, 106856. [CrossRef]

241. Barnes, B.B.; Hu, C. Island building in the South China Sea: Detection of turbidity plumes and artificial islands using Landsat and MODIS data. Sci. Rep. 2016, 6, 33194. [CrossRef] [PubMed]

242. Sabia, R.; Fernandez-Prieto, D.; Shutler, J.; Donlon, C.; Land, P.; Reul, N. Remote sensing of surface ocean PH exploiting sea surface salinity satellite observations. In Proceedings of the 2015 IEEE International Geoscience and Remote Sensing Symposium (IGARSS), Milan, Italy, 26-31 July 2015; pp. 106-109.

243. Markogianni, V.; Kalivas, D.; Petropoulos, G.; Dimitriou, E. An appraisal of the potential of Landsat 8 in estimating chlorophyll-a, ammonium concentrations and other water quality indicators. Remote Sens. 2018, 10, 1018. [CrossRef] 
244. Pahlevan, N.; Schott, J.R. Leveraging EO-1 to evaluate capability of new generation of Landsat sensors for coastal/inland water studies. IEEE J. Sel. Top. Appl. Earth Obs. Remote Sens. 2013, 6, 360-374. [CrossRef]

245. Chang, N.-B.; Imen, S.; Vannah, B. Remote sensing for monitoring surface water quality status and ecosystem state in relation to the nutrient cycle: A 40-year perspective. Crit. Rev. Environ. Sci. Technol. 2015, 45, 101-166. [CrossRef]

246. Shang, D.; Xu, H. Qualitative dynamics of suspended particulate matter in the changjiang estuary from geostationary ocean color images: An empirical, regional modeling approach. Sensors 2018, 18, 4186. [CrossRef] [PubMed]

247. Moomaw, W.R.; Chmura, G.L.; Davies, G.T.; Finlayson, C.M.; Middleton, B.A.; Natali, S.M.; Perry, J.E.; Roulet, N.; Sutton-Grier, A.E. Wetlands in a changing climate: Science, policy and management. Wetlands 2018, 38, 183-205. [CrossRef]

248. Thorhaug, A.; Berlyn, G.P.; Poulos, H.M.; Goodale, U.M. Pollutant tracking for 3 Western North Atlantic sea grasses by remote sensing: Preliminary diminishing white light responses of Thalassia testudinum, Halodule wrightii, and Zostera marina. Mar. Pollut. Bull. 2015, 97, 460-469. [CrossRef]

249. Elso, M.Z.; Manent, P.; Luque, A.; Ramdani, M.; Robaina, R.R. Genetic description and remote sensing techniques as management tools for Zostera noltii seagrass populations along the Atlantic Moroccan Coast. J. Coast. Res. 2017, 331, 78-87. [CrossRef]

250. Bakirman, T.; Gumusay, M.U.; Tuney, I. Mapping of the seagrass cover along the Mediterranean coast of Turkey using Landsat 8 OLI images. Int. Arch. Photogramm. Remote Sens. Spat. Inf. Sci. 2016, 41, 1103-1105. [CrossRef]

251. Hill, V.J.; Zimmerman, R.C.; Bissett, W.P.; Dierssen, H.; Kohler, D.D.R. Evaluating light availability, seagrass biomass, and productivity using hyperspectral airborne remote sensing in Saint Joseph's Bay, Florida. Estuaries Coasts 2014, 37, 1467-1489. [CrossRef]

252. Duffy, J.P.; Pratt, L.; Anderson, K.; Land, P.E.; Shutler, J.D. Spatial assessment of intertidal seagrass meadows using optical imaging systems and a lightweight drone. Estuar. Coast. Shelf Sci. 2018, 200, 169-180. [CrossRef]

253. Gumusay, M.U.; Bakirman, T.; Kizilkaya, I.T.; Aykut, N.O. A review of seagrass detection, mapping and monitoring applications using acoustic systems. Eur. J. Remote Sens. 2019, 52, 1-29. [CrossRef]

254. Wenger, A.S.; Williamson, D.H.; Da Silva, E.T.; Ceccarelli, D.M.; Browne, N.K.; Petus, C.; Devlin, M.J. Effects of reduced water quality on coral reefs in and out of no-take marine reserves. Conserv. Biol. 2016, 30, 142-153. [CrossRef] [PubMed]

255. Xu, J.; Zhao, D. Review of coral reef ecosystem remote sensing. Acta Ecol. Sin. 2014, 34, 19-25. [CrossRef]

256. Purkis, S.J. Remote sensing tropical coral reefs: The view from above. Ann. Rev. Mar. Sci. 2018, 10, 149-168. [CrossRef]

257. Xing, Q.; Guo, R.; Wu, L.; An, D.; Cong, M.; Qin, S.; Li, X. High-resolution satellite observations of a new hazard of golden tides caused by floating sargassum in winter in the Yellow Sea. IEEE Geosci. Remote Sens. Lett. 2017, 14, 1815-1819. [CrossRef]

258. Zhang, J.; Shi, J.; Gao, S.; Huo, Y.; Cui, J.; Shen, H.; Liu, G.; He, P. Annual patterns of macroalgal blooms in the Yellow Sea during 2007-2017. PLoS ONE 2019, 14, e0210460. [CrossRef]

259. Heupel, M.; Knip, D.; Simpfendorfer, C.; Dulvy, N. Sizing up the ecological role of sharks as predators. Mar. Ecol. Prog. Ser. 2014, 495, 291-298. [CrossRef]

260. Njoku, E.G. Satellite remote sensing of sea surface temperature. In Surface Waves and Fluxes; Geernaert, G.L., Plant, W.L., Eds.; Springer: Dordrecht, The Netherlands, 1990; pp. 311-338. ISBN 978-94-009-0627-3.

261. Azmi, S.; Agarwadkar, Y.; Bhattacharya, M.; Apte, M.; Inamdar, A.B. Monitoring and trend mapping of sea surface temperature (SST) from MODIS data: A case study of Mumbai coast. Environ. Monit. Assess. 2015, 187, 165. [CrossRef] [PubMed]

262. Waga, H.; Hirawake, T.; Fujiwara, A.; Kikuchi, T.; Nishino, S.; Suzuki, K.; Takao, S.; Saitoh, S.-I. Differences in rate and direction of shifts between phytoplankton size structure and sea surface temperature. Remote Sens. 2017, 9, 222. [CrossRef]

263. Robles-Tamayo, C.; Valdez-Holguín, J.; García-Morales, R.; Figueroa-Preciado, G.; Herrera-Cervantes, H.; López-Martínez, J.; Enríquez-Ocaña, L. Sea Surface Temperature (SST) Variability of the eastern coastal zone of the Gulf of California. Remote Sens. 2018, 10, 1434. [CrossRef] 
264. Nicholls, R.J.; Wong, P.P.; Burket, V.R.; Codignotto, J.; Hay, J.E.; McLean, R.F.; Ragoonaden, S.; Woodroffe, C.D. Climate Change 2014 Impacts, Adaptation, and Vulnerability; Field, C.B., Barros, V.R., Dokken, D.J., Mach, K.J., Mastrandrea, M.D., Eds.; Cambridge University Press: Cambridge, UK, 2014; ISBN 9781107415379.

265. Liu, X.; Huang, W.; Gill, E.W. Estimation of significant wave height from X-band marine radar images based on ensemble empirical mode decomposition. IEEE Geosci. Remote Sens. Lett. 2017, 14, 1740-1744. [CrossRef]

266. Kammerer, J.A.; Hackett, E.E. Use of proper orthogonal decomposition for extraction of ocean surface wave fields from X-band radar measurements of the sea surface. Remote Sens. 2017, 9, 881. [CrossRef]

267. Leshchinsky, B.; Olsen, M.J.; Mohney, C.; Glover-Cutter, K.; Crook, G.; Allan, J.; Bunn, M.; O’Banion, M.; Mathews, N. Mitigating coastal landslide damage. Science 2017. [CrossRef] [PubMed]

268. Li, G.; Lei, Y.; Yao, H.; Wu, S.; Ge, J. The influence of land urbanization on landslides: An empirical estimation based on Chinese provincial panel data. Sci. Total Environ. 2017, 595, 681-690. [CrossRef] [PubMed]

269. Sekovski, I.; Newton, A.; Dennison, W.C. Megacities in the coastal zone: Using a driver-pressure-state-impactresponse framework to address complex environmental problems. Estuar. Coast. Shelf Sci. 2012, 96, 48-59. [CrossRef]

270. Syvitski, J.P.M.; Kettner, A.J.; Overeem, I.; Hutton, E.W.H.; Hannon, M.T.; Brakenridge, G.R.; Day, J.; Vörösmarty, C.; Saito, Y.; Giosan, L.; et al. Sinking deltas due to human activities. Nat. Geosci. 2009, 2, 681-686. [CrossRef]

271. Crosetto, M.; Monserrat, O.; Cuevas-González, M.; Devanthéry, N.; Crippa, B. Persistent scatterer interferometry: A review. ISPRS J. Photogramm. Remote Sens. 2016, 115, 78-89. [CrossRef]

272. Feng, L.; Hou, X.; Li, J.; Zheng, Y. Exploring the potential of Rayleigh-corrected reflectance in coastal and inland water applications: A simple aerosol correction method and its merits. ISPRS J. Photogramm. Remote Sens. 2018, 146, 52-64. [CrossRef]

273. Anderson, D.M. Approaches to monitoring, control and management of harmful algal blooms (HABs). Ocean Coast. Manag. 2009, 52, 342-347. [CrossRef] [PubMed]

274. Zhao, J.; Temimi, M.; Ghedira, H. Characterization of harmful algal blooms (HABs) in the Arabian Gulf and the Sea of Oman using MERIS fluorescence data. ISPRS J. Photogramm. Remote Sens. 2015, 101, 125-136. [CrossRef]

275. Goela, P.C.; Icely, J.; Cristina, S.; Newton, A.; Moore, G.; Cordeiro, C. Specific absorption coefficient of phytoplankton off the Southwest coast of the Iberian Peninsula: A contribution to algorithm development for ocean colour remote sensing. Cont. Shelf Res. 2013, 52, 119-132. [CrossRef]

276. Alvarado, M.; Gonzalez, F.; Fletcher, A.; Doshi, A. Towards the development of a low cost airborne sensing system to monitor dust particles after blasting at open-pit mine sites. Sensors 2016, 16, 1028. [CrossRef]

277. Brakenridge, G.R.; Syvitski, J.P.M.; Overeem, I.; Higgins, S.A.; Kettner, A.J.; Stewart-Moore, J.A.; Westerhoff, R. Global mapping of storm surges and the assessment of coastal vulnerability. Nat. Hazards 2013, 66, 1295-1312. [CrossRef]

278. $\mathrm{Xu}, \mathrm{X} . ; \mathrm{Xu}, \mathrm{Z}$.; Chen, L.; Li, C. How does industrial waste gas emission affect health care expenditure in different regions of China: An application of bayesian quantile regression. Int. J. Environ. Res. Public Health 2019, 16, 2748. [CrossRef] [PubMed]

279. Neumann, P.P.; Hernandez Bennetts, V.; Lilienthal, A.J.; Bartholmai, M.; Schiller, J.H. Gas source localization with a micro-drone using bio-inspired and particle filter-based algorithms. Adv. Robot. 2013, 27, 725-738. [CrossRef]

280. Zhang, W.; Villarini, G.; Vecchi, G.A.; Smith, J.A. Urbanization exacerbated the rainfall and flooding caused by hurricane Harvey in Houston. Nature 2018, 563, 384-388. [CrossRef]

281. Patricola, C.M.; Wehner, M.F. Anthropogenic influences on major tropical cyclone events. Nature 2018, 563, 339-346. [CrossRef]

282. Barnard, S.; Elliott, M. The 10-tenets of adaptive management and sustainability: An holistic framework for understanding and managing the socio-ecological system. Environ. Sci. Policy 2015, 51, 181-191. [CrossRef]

283. Butt, M.A.; Nisar, K.; Mahmood, S.A.; Sami, J.; Qureshi, J.; Jaffer, G. Toward GIS-based approach for identification of ecological sensitivity areas: Multi-criteria evaluation technique for promotion of tourism in Soon Valley, Pakistan. J. Indian Soc. Remote Sens. 2019, 47, 1527-1536. [CrossRef]

284. Warren, C.; Dupont, J.; Abdel-Moati, M.; Hobeichi, S.; Palandro, D.; Purkis, S. Remote sensing of Qatar nearshore habitats with perspectives for coastal management. Mar. Pollut. Bull. 2016, 105, 641-653. [CrossRef] [PubMed] 
285. De Araujo Barbosa, C.C.; Atkinson, P.M.; Dearing, J.A. Remote sensing of ecosystem services: A systematic review. Ecol. Indic. 2015, 52, 430-443. [CrossRef]

286. Vaz, A.S.; Gonçalves, J.F.; Pereira, P.; Santarém, F.; Vicente, J.R.; Honrado, J.P. Earth observation and social media: Evaluating the spatiotemporal contribution of non-native trees to cultural ecosystem services. Remote Sens. Environ. 2019, 230, 111193. [CrossRef]

287. Foo, S.A.; Asner, G.P. Scaling up coral reef restoration using remote sensing technology. Front. Mar. Sci. 2019, 6, 79. [CrossRef]

288. Lay-Ekuakille, A.; Durickovic, I.; Lanzolla, A.; Morello, R.; De Capua, C.; Girão, P.S.; Postolache, O.; Massaro, A.; Van Biesen, L. Effluents, surface and subterranean waters monitoring: Review and advances. Measurement 2019, 137, 566-579. [CrossRef]

289. Levin, N.; Ali, S.; Crandall, D.; Kark, S. World Heritage in danger: Big data and remote sensing can help protect sites in conflict zones. Glob. Environ. Chang. 2019, 55, 97-104. [CrossRef]

290. Hildmann, H.; Kovacs, E. Review: Using unmanned aerial vehicles (UAVs) as mobile sensing platforms (MSPs) for disaster response, civil security and public safety. Drones 2019, 3, 59. [CrossRef]

291. Pepe, M.; Fregonese, L.; Scaioni, M. Planning airborne photogrammetry and remote-sensing missions with modern platforms and sensors. Eur. J. Remote Sens. 2018, 51, 412-436. [CrossRef]

292. Boukoberine, M.N.; Zhou, Z.; Benbouzid, M. A critical review on unmanned aerial vehicles power supply and energy management: Solutions, strategies, and prospects. Appl. Energy 2019, 255, 113823. [CrossRef]

293. Watts, A.C.; Ambrosia, V.G.; Hinkley, E.A. Unmanned aircraft systems in remote sensing and scientific research: Classification and considerations of use. Remote Sens. 2012, 4, 1671-1692. [CrossRef]

294. Tahir, A.; Böling, J.; Haghbayan, M.-H.; Toivonen, H.T.; Plosila, J. Swarms of unmanned aerial vehicles-A Survey. J. Ind. Inf. Integr. 2019. [CrossRef]

295. Fettermann, T.; Fiori, L.; Bader, M.; Doshi, A.; Breen, D.; Stockin, K.A.; Bollard, B. Behaviour reactions of bottlenose dolphins (Tursiops truncatus) to multirotor unmanned aerial vehicles (UAVs). Sci. Rep. 2019, 9, 8558. [CrossRef]

296. Las Fargeas, J.; Kabamba, P.; Girard, A. Cooperative surveillance and pursuit using unmanned aerial vehicles and unattended ground sensors. Sensors 2015, 15, 1365-1388. [CrossRef] [PubMed]

297. Jorge, V.; Granada, R.; Maidana, R.; Jurak, D.; Heck, G.; Negreiros, A.; Dos Santos, D.; Gonçalves, L.; Amory, A. A Survey on unmanned surface vehicles for disaster robotics: Main challenges and directions. Sensors 2019, 19, 702. [CrossRef] [PubMed]

298. Guo, T.; Capra, A.; Troyer, M.; Gruen, A.; Brooks, A.J.; Hench, J.L.; Schmitt, R.J.; Holbrook, S.J.; Dubbini, M. Accuracy assessment of underwater photogrammetric three dimensional modelling for coral reefs. ISPRS Int. Arch. Photogramm. Remote Sens. Spat. Inf. Sci. 2016. [CrossRef]

299. Bryson, M.; Ferrari, R.; Figueira, W.; Pizarro, O.; Madin, J.; Williams, S.; Byrne, M. Characterization of measurement errors using structure-from-motion and photogrammetry to measure marine habitat structural complexity. Ecol. Evol. 2017, 7, 5669-5681. [CrossRef]

300. Zhuang, Y.; Huang, H.; Sharma, S.; Xu, D.; Zhang, Q. Cooperative path planning of multiple autonomous underwater vehicles operating in dynamic ocean environment. ISA Trans. 2019. [CrossRef]

301. Zheng, G.; DiGiacomo, P.M. Uncertainties and applications of satellite-derived coastal water quality products. Prog. Oceanogr. 2017, 159, 45-72. [CrossRef]

302. Nitti, D.; Bovenga, F.; Chiaradia, M.; Greco, M.; Pinelli, G. Feasibility of using synthetic aperture radar to aid UAV navigation. Sensors 2015, 15, 18334-18359. [CrossRef]

303. Marques, E.R.B.; Ribeiro, M.; Pinto, J.; Sousa, J.B.; Martins, F. Towards programmable coordination of unmanned vehicle networks. IFAC Pap. 2015, 48, 256-261. [CrossRef]

304. Qdais, H.A.; Shatnawi, N. Assessing and predicting landfill surface temperature using remote sensing and an artificial neural network. Int. J. Remote Sens. 2019, 40, 9556-9571. [CrossRef]

305. Ma, L.; Liu, Y.; Zhang, X.; Ye, Y.; Yin, G.; Johnson, B.A. Deep learning in remote sensing applications: A meta-analysis and review. ISPRS J. Photogramm. Remote Sens. 2019, 152, 166-177. [CrossRef]

306. Gonzalez, L.; Montes, G.; Puig, E.; Johnson, S.; Mengersen, K.; Gaston, K. Unmanned aerial vehicles (UAVs) and artificial intelligence revolutionizing wildlife monitoring and conservation. Sensors 2016, $16,97$. [CrossRef] [PubMed] 
307. Bartolini, S.; Mecocci, A.; Pozzebon, A.; Zoppetti, C.; Bertoni, D.; Sarti, G.; Caiti, A.; Costanzi, R.; Catani, F.; Ciampalini, A.; et al. Augmented virtuality for coastal management: A holistic use of in situ and remote sensing for large scale definition of coastal dynamics. ISPRS Int. J. Geo. Inf. 2018, 7, 92. [CrossRef]

308. Granell, C.; Kamilaris, A.; Kotsev, A.; Ostermann, F.O.; Trilles, S. Internet of things. In Manual of Digital Earth; Guo, H., Goodchild, M.F., Annoni, A., Eds.; Springer: Singapore, 2020; pp. 387-423. ISBN 978-981-32-9915-3.

309. Xu, G.; Shi, Y.; Sun, X.; Shen, W. Internet of Things in marine environment monitoring: A Review. Sensors 2019, 19, 1711. [CrossRef] [PubMed]

310. Groom, S.; Sathyendranath, S.; Ban, Y.; Bernard, S.; Brewin, R.; Brotas, V.; Brockmann, C.; Chauhan, P.; Choi, J.; Chuprin, A.; et al. Satellite ocean colour: Current status and future perspective. Front. Mar. Sci. 2019, 6, 485. [CrossRef]

(C) 2020 by the authors. Licensee MDPI, Basel, Switzerland. This article is an open access article distributed under the terms and conditions of the Creative Commons Attribution (CC BY) license (http://creativecommons.org/licenses/by/4.0/). 